\title{
Uniformity and diversity in the syntax of evaluative vocatives
}

\section{Norbert Corver}

Received: 1 December 2006 / Accepted: 26 September 2007 /

Published online: 11 March 2008

(C) The Author(s) 2008

\begin{abstract}
This article investigates the internal syntax of evaluative vocative expressions (e.g., You idiot!). This construction superficially consists of a second person pronoun and an epithet noun. It turns out that this construction type has different morphosyntactic manifestations across languages/dialects (abstractly: you $_{\mathrm{NOM}}$ idiot!; you $\mathrm{ACC} / \mathrm{OBL}$ idiot!; your idiot!). The paper aims at giving a uniform account for the 'underlying' syntax of this construction type. It is argued that this construction has the 'underlying' syntax of a possessive noun phrase. More particularly, the second person pronoun starts out as (part of) a PP-predicate and undergoes leftward predicate displacement within the vocative noun phrase. The major dimensions of (morpho)syntactic diversity are related to the following properties: (1) the nature of the predicate displacement operation involved (i.e., predicate inversion and/or predicate fronting); (2) the overtness versus covertness of the small clause head X, which is part of the vocative expression; (3) the case form of the second person pronoun. According to the structural analysis proposed in this article, evaluative vocative expressions form a further illustration of the structural uniformity that is hidden behind superficial diversity.
\end{abstract}

Keywords Epithet - Evaluative vocative - Morphosyntactic variation ·

Nominal copula $\cdot$ Possessive noun phrase $\cdot$ Predication $\cdot$ Predicate displacement .

Spurious indefinite article

\section{Jespersen's observation}

In chapter VII ("The Three Ranks") of The Philosophy of Grammar, Jespersen (1977) discusses the phenomenon that there is a certain scheme of subordination in connected speech, that is, when two words combine, "there is one word of supreme importance to which the others are joined as subordinates" (p. 96). He goes on to say that "[T]his chief word is defined (qualified, modified) by another word, which in its turn may be defined (qualified, modified) by a third word, etc. We are thus led to

N. Corver $(\bowtie)$

Utrecht Institute of Linguistics-OTS, Utrecht University, Trans 10, 3512JK Utrecht, The Netherlands e-mail: norbert.corver@let.uu.nl 
establish different "ranks" of words according to their mutual relations as defined or defining" (p. 96). Jespersen illustrates his theory of ranks (i.e., levels of subordination) with the example extremely hot weather, in which the noun weather is what he calls the primary word (i.e., the chief idea; rank I). The adjective hot combines with the noun - a type of combination called junction - and, as such, is a word of secondary rank (a so-called adjunct). The adverb extremely, finally, enters into a junction relationship with hot and forms a word of tertiary rank (a so-called subjunct). In his discussion, Jespersen also considers ways in which two substantives combine into larger syntactic units. A sequence like Shelley's poems, featuring the bound morpheme $-s$, is analyzed as 'secondary noun (i.e., adjunct) + primary noun', and so is a sequence like (a) silk dress, in which the two substantive elements are juxtaposed. Jespersen (pp. 98-99) further observes that "[I]n some cases when we want to join two substantival ideas it is found impossible or impracticable to make one of them into an adjunct of the other by simple juxtaposition; here languages often have recourse to the 'definitive genitive' or a corresponding prepositional combination [...]."1 He then gives examples like those in (1).

$$
\begin{aligned}
& \text { a. la cite de Rome } \\
& \text { b. the city of Rome }
\end{aligned}
$$

a. un amour d'enfant

b. a beauty of a child
(French)

(English)

(French)

(English)

Interestingly, Jespersen does not explicitly state what the ranking is for these junctions of 'substantival ideas'. This may be caused by the incongruous relationship between the two substantives. In (2a), for example, amour seems to be the primary syntactic head; it combines with the indefinite article $u n$ and is followed by the phrase d'enfant, which superficially looks like a secondary element, just like d'un enfant in un livre d'un enfant 'a book of a child'. From a semantic point of view, though, amour behaves like a secondary substantive (i.e., adjunct). It qualifies the substantive enfant, that is, it assigns the property of '(being like a) beauty/treasure' to the substantive idea 'child'. After his presentation of examples like (1) and (2), Jespersen (p. 99) argues that these junctions of substantival ideas are "[...] connected with the Scandinavian use of a possessive pronoun dit foe 'you fool' and to the Spanish Pobrecitos de nosotros! [Poor of us; 'Poor us!'; NC] Desdichada de mi! [Poor of me; 'Poor me!'; NC]." Unfortunately, Jespersen is not explicit about the exact nature of the connection. But from the Spanish patterns, which as a matter of fact involve a combination of an adjective with a substantive, one might draw the conclusion that Jespersen has in mind an analysis of these constructions in which the first lexical element constitutes the adjunct (i.e., the secondary/qualifying element) and the second lexical element has the primary rank.

In current generative studies on the syntax of noun phrases, it has also been observed that there is a certain connection between (some of) the above-mentioned construction types discussed by Jespersen (see, among others, Kayne 1994; Den

\footnotetext{
${ }^{1}$ The definitive genitive is illustrated in Jespersen (1977) by the Latin example urbs Romae (city-NOM Rome-GEN, 'the city of Rome').
} 
Dikken 2006). This connection is defined in terms of the notion of predication. At an intuitive level, some sort of predication relation seems to hold between the two substantives in (1) and (2): i.e., 'Rome is city'; 'child is (like a) beauty/treasure'. And the Spanish expressions can also be straightforwardly paraphrased in terms of a predication relationship: 'We are poor'; 'I am poor'. Another remarkable piece of symmetry between these constructions is the fact that the predicate (cité, city, amour, beauty, pobrecitos, desdichada) precedes the nominal subject. This inverted word order of the subject-predicate relationship has recently been analyzed in terms of the application of (leftward) predicate displacement within the noun phrase (see below for details). The predicate originates in a post-subject position and ends up in its surface position as a result of DP-internal leftward predicate movement. Schematically, abstracting away from details, this is shown in (3):
a. [the [sC Rome [Pred city]]] $\rightarrow$ [the [city $]_{\mathrm{i}}$ of [sC Rome $\left.\left.\mathrm{t}_{\mathrm{i}}\right]\right]$
b. $\quad[\mathrm{a}[\mathrm{sC}$ fellow [Pred devil $]]] \rightarrow\left[\right.$ a $[\text { devil }]_{\mathrm{i}}$ of a $\left[\mathrm{sC}\right.$ fellow $\left.\left.\mathrm{t}_{\mathrm{i}}\right]\right]$
c. $\quad[$ sc nosotros $[$ Pred pobrecitos $]] \rightarrow\left[[\text { pobrecitos }]_{\mathrm{i}}\right.$ de $\left[\mathrm{sC}\right.$ nosotros $\left.\left.\mathrm{t}_{\mathrm{i}}\right]\right]$

If Jespersen's intuition about the relationship of the above-mentioned syntactic constructs is right, and if, in line with current thinking, the constructs in (3) feature the phenomenon of predicate displacement, then one might arrive at the conclusion that the fourth syntactic construction mentioned by Jespersen, that is, dit foe! (translated by him as 'you fool!'), also features the syntactic operation of predicate displacement. This would mean that the second person pronominal (Danish: dit) originates as a predicate following the subject $(f c e)$ and ends up in a position preceding the subject as a result of predicate displacement. It is this predicate displacement analysis of vocative expressions like Danish dit foe! (and equivalent expressions in other - mostly Germanic - languages/dialects) that I will explore in this article.

On the basis of Jespersen's translation of dit fae!, that is, 'you fool!', one might be surprised by the suggestion that the pronominal element is the predicate. An interpretation according to which 'fool' is the nominal predicate that predicates over 'you' seems to be more likely. Compare, for example, the clause 'you (are) a fool'. On the basis of the literal translation, though, the suggestion that the pronoun is an inverted predicate (and not a subject in a predication relationship) becomes more plausible: dit fce! literally means: 'your cattle ${ }_{\mathrm{sg}}$. ${ }^{2}$ Importantly, the pronoun is a possessive pronoun, meaning 'your' rather than 'you'. In the recent generative literature (cf., e.g., Den Dikken 1998), the suggestion has been made that in DPinternal possessive relations the possessor starts out as a (prepositional) predicate following the possessee (e.g., [car [(to) you]]) and undergoes DP-internal predicate inversion, yielding the sequence: you(-r) car. $^{3}$ The 'underlying' meaning would thus

\footnotetext{
2 Thus, a paraphrase like 'you (stupid) cow!' is closer to the literal meaning than Jespersen's 'you fool!'.

${ }^{3}$ This characterization of the predicate inversion analysis of the DP-internal possessive relationship is, of course, very simplified. A more detailed analysis will be presented in the course of this article. It should further be noted that this predicate inversion analysis of the DP-internal possessive relationship is inspired by recent analyses of the clause-internal possessive have-relationship in terms of predicate inversion. In simplified and global terms, John has a car derives from the underlying copular construction 'a car is to John', where the possessor (i.e., (to) John) functions as a predicate and to is a locative/dative preposition. (cf. Freeze 1992). The verbal form have is conceived of as the spell-out of the complex head be + to, where to has been incorporated into the copular verb be.
} 
roughly correspond to: 'a car is to me'. If we extend this approach towards DPinternal possession to the dit fae!-construction, the second person pronoun would start out as a predicate (i.e., a PP) which predicates over fae. The corresponding 'underlying' meaning could informally be stated as follows: '(the property of being a) cattle/cow (i.e., 'a fool') is to you'. 4

Thus, the idea of analyzing evaluative vocative expressions in terms of predicate displacement is prompted by its parallelism with 'regular' possessive noun phrases. As we will see in the course of this paper, empirical support for the extension of this predicate displacement analysis to evaluative vocative expressions will come from the appearance of certain grammatical elements - most particularly, the so-called spurious indefinite article een ('a') (cf. Bennis et al. 1998) - in this nominal construction type. As has been argued by Bennis, Corver, and Den Dikken, this grammatical element typically shows up in contexts of DP-internal predicate movement. Or, to put it differently, the presence of predicate displacement can be diagnosed on the basis of the appearance of this grammatical element.

In this paper, I will take a comparative perspective on this construction type: it turns out that the second person pronoun displays interesting cross-linguistic variation in its formal appearance. More particularly, besides the Danish pattern 'your fool!' (i.e., Danish dit fae!), which features a possessive pronoun, we find the

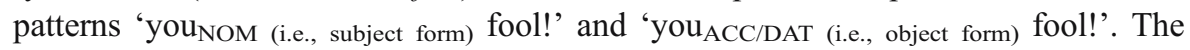
question obviously arises whether these patterns, which display a similar word order (i.e., pronoun + noun) but are different as regards the form of the pronoun, should receive a uniform analysis (in casu a predicate displacement analysis) or not.

The article is organized as follows: In Section 2, I will start my discussion of what I will call 'evaluative vocatives' with an examination of the properties of the noun that combines with the second person pronoun. It will be identified as an epithet noun; it has an intensifying meaning and expresses a value of judgment. Section 3 provides a brief description of the various surface manifestations of the evaluative vocative expression across (some) dialects and languages. Section 4 provides some initial insight into the syntax of this vocative expression by means of a comparison with expressions of the type we linguists, which also feature a juxtaposition of a pronominal element and a noun. The outcome of this comparison will be that the evaluative vocative expression should receive a syntactic analysis which is different from the analysis of the we linguists-construction. In Section 5, I introduce the phenomenon of DP-internal predicate displacement, paving the way for my analysis of the evaluative vocatives. In Sections 6, 7, and 8, I provide an analysis of the various surface manifestations of the evaluative vocative expression. A central claim will be that the syntactic operation of predicate displacement is active in the derivation of the evaluative vocative expressions. Two grammatical elements are identified, viz. the so-called nominal copula and the spurious indefinite article,

\footnotetext{
${ }^{4}$ English nominal expressions that are quite comparable to the Danish dit fee!-construction are the following: Your Highness, Your Excellency, Your Eminence, Your Majesty, Your Holiness. The possessive meaning associated with an expression like Your Highness can be paraphrased as follows: 'Highness is to you'. In other words, Highness is the subject and $(P+)$ you is the underlying predicate.
} 
whose appearance has been shown to be typical for noun phrases featuring the phenomenon of predicate displacement. In Section 9, the Danish pattern dit fae!, observed by Jespersen, is also analyzed in terms of DP-internal predicate displacement. In Section 10, I show that the dimensions of morphosyntactic diversity displayed by the you fool!-construction are also found with the so-called wat voor $N$-construction, which has also been analyzed in terms of DP-internal predicate displacement. Section 11 concludes this article.

\section{N2 as a degree noun}

The vocative expression at issue is typically a combination of a second person pronoun and an evaluating epithet noun. ${ }^{5}$ The vocative noun is an epithet: its use is intended as a judgment of value. This is illustrated by the examples in (4) from Dutch, where the epithet noun indicates goodness (4a), badness (4b), and cuteness (4c). Given the evaluating function of the noun, I will call these nominal constructions 'evaluative vocatives'. 6
a. Jij kanjer!
you colossus
b. Jij idioot!
you idiot
c. Jij duifje van me!
you pigeon-DIM of me

The noun has an intensifying meaning and may be qualified as a degree noun in the sense of Bolinger (1972; alternatively: a scalar noun; cf. Matushansky 2002). The phrase jij idioot! in (4b), for example, expresses that the addressee has the quality of being an idiot to a high degree. As shown in (5), nouns that do not have

\footnotetext{
${ }^{5}$ As pointed out by a reviewer, a first person pronoun can also appear in evaluative vocative expressions in languages such as Swedish and Norwegian. This is illustrated by the examples (1) and (2), which are drawn from Google:
}

(i) Och jag, min idiot, gav henne jackan och gick (Swedish) And I, my idiot, gave her jacket-def and went

'And I, stupid me, gave her the jacket and left.'

(ii)

$$
\begin{aligned}
& \text { Jeg, min idiot, svelgte alt han sa } \\
& \text { I, my idiot, swallowed everything he said } \\
& \text { 'I, stupid idiot, believed everything he said.' }
\end{aligned}
$$

(Norwegian)

Potts and Roeper (2006) give the example Ich Idiot! (I idiot) for German.

\footnotetext{
${ }^{6}$ In this article, I will also refer to this vocative expression as the you idiot!-construction.
} 
this intensifying meaning (i.e., non-degree nouns) do not form a vocative phrase together with the second person pronoun.,
a. *Jij jongen!
you boy
b. *Jij tandarts!
you dentist
c. *Jij leraar!
you teacher

The intensifying meaning of the nouns in (4) versus the non-intensifying meaning of those in (5) can be further illustrated by means of a number of phenomena. First of all, the nouns in (5) can combine with the intensifier $z o$ 'n 'such a' together with a result clause; see (6). As shown in (7), the non-degree nouns are not allowed in this configuration:
a. Het is zo 'n eikel dat iedereen hem haat It is such a jerk that everybody him hates
b. Het is zo 'n schatje dat je 'm meteen wilt kopen It is such a darling that you it (e.g., a kitten) inmediately want to.buy

(7) a. *Het is zo 'n jongen dat je hem nooit wilt tegenkomen It is such a boy that you him never want to.meet

b. *Het is zo 'n tandarts dat je je tanden maar beter goed kunt poetsen It is such a dentist that you your teeth PRT better well can brush

Of course, zo'n can combine with non-degree nouns such as jongen and tandarts when it has an identifying meaning: that is, 'a boy/dentist like that'.
a. Zo 'n jongen doet dat niet
Such a boy does that not
'A boy like that does not do that.'
b. Zo 'n tandarts wil ik ook
Such a dentist want I too
'I also want a dentist like him.'

A second illustration of the intensifying meaning of the nouns in (4) comes from their occurrence in exclamative constructions of the type 'epithet noun + relative clause'. As shown in (9), degree nominals can occur as the head of the exclamative

\footnotetext{
${ }^{7}$ These limitations on the noun that combines with the second person pronoun are reminiscent of the facts for Lebanese Arabic epithets as discussed in Aoun and Choueiri (2000).

${ }^{8}$ Although nouns like those in (5) do not lexically have an intensifying meaning, it is possible to pragmatically endow a normally non-scalar noun with a degree/scalar reading. For example, Dutch schoolmeester 'schoolmaster' is perfectly usable in a context such as (5c) once it is interpreted stereotypically. See Den Dikken (2006, p. 174) for a brief discussion of this.
} 
noun phrase. The examples in (10) illustrate that non-degree nominals such as jongen and vrouw do not occur in this structural environment.

(9) a. Eikel die je bent!

Jerk who you are

'You are such a jerk!'

b. Kreng dat je bent!

Bitch that you are!

'You are such a bitch!'

(10) a. *Jongen die je bent!

Boy who you are

'You are such a boy!'

b. *Vrouw die je bent!

Woman who you are

'You are such a woman!'

A third structural environment that distinguishes degree nouns from non-degree nouns is the $N$ of $N$-construction (cf. Bolinger 1972, p. 75, fn. 14): ${ }^{9}$
a. die eikel van een Jan
that jerk of a Jan
b. dat kreng van een vrouw
that bitch of a woman

In each of these examples, the first noun (i.e., the degree noun) qualifies the second noun. In (11b), for example, the intensifying noun kreng predicates over the noun vrouw: 'woman is (like) a bitch'. As exemplified in (12), non-degree nouns such as those in (5) do not occur in the $N$ of $N$ construction:

(12) a. *die jongen van een Jan

that boy of a Jan

b. *die vrouw van een Marie

that woman of a Marie

c. *die leraar van een man

that teacher of a man

Not unexpectedly, the $N$ of $N$ construction can co-occur with the second person pronoun, forming a vocative construction:

(13) a. Jij eikel van een jongen!

you jerk of a boy

b. Jij kreng van een wijf!

you bitch of a woman

\footnotetext{
${ }^{9}$ Bolinger (1972) gives the following pairs: that baby of a brother of yours (degree) versus *that lad of a brother of yours (nondegree); that shyster of a lawyer (degree) versus *that lawyer of a son of yours (nondegree).
} 
Notice also that if the intensifying meaning is not part of the noun, it can be provided by means of an intensifying element like a gradable adjective. Compare, for example, the following evaluative vocative expressions with those in $(5):{ }^{10}$
a. Jij vervelende jongen!
you annoying boy
b. Jij stomme leraar! you stupid teacher

Thus far, I have argued that the second element in the evaluative vocative noun phrase must be an epithet noun. In the next section, I will consider some grammatical properties of the pronominal part of this vocative expression.

\section{Variation in the pronominal part}

As shown by the Dutch example in (15), the pronoun of the 'you idiot' phrase must be a strong pronominal form; the weak (clitic) pronominal form is excluded.

$$
\begin{array}{lll}
\text { a. } & \text { Jij } & \text { idioot! } \\
& \text { you }_{\text {strong }} & \text { idiot } \\
\text { b. } & \text { *Je } & \text { idioot! } \\
& \text { you }_{\text {weak }} & \text { idiot }
\end{array}
$$

One of the most remarkable properties of the pronominal part is the crosslinguistic variation it displays in its formal appearance (see also Potts and Roeper 2006). In present-day Dutch (16a) and German (16b), we find the second person pronoun in its nominative form (i.e., the subject form). As shown by (16c), the nominative form is also found in older variants of Dutch.
a. Jij idioot!
(Dutch)
b. $\mathrm{Du}$ Idiot!
(German) you NOM $_{\text {idiot }}$
c. Gaat heen, ghy

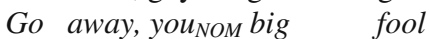

\footnotetext{
${ }^{10}$ Notice that, thanks to the presence of the gradable attributive adjective, the following constructions are also permitted [compare with (7a) and (10a)]:

(i) a. Het is zo 'n vervelende jongen dat je hem nooit wilt tegenkomen

It is such a annoying boy that you him never want to.meet

b. Vervelende jongen die je bent!

Annoying boy who you are
}

Notice, however, that despite the presence of a gradable adjective the following $N$ of $N$ construction is not permitted:

(ii) $\quad *$ Die vervelende man van een tandarts

That annoying man of a dentist 
Interestingly, the object form (accusative/oblique) of the second person pronoun is also attested, namely in certain (older and dialectal) variants of Dutch (cf. Overdiep 1935, Weijnen 1966, 1971) and in Afrikaans.
a. Jou duyvelskop!
(17 ${ }^{\text {th }}$ century Dutch; Kern 1927)
you ${ }_{A C C / O B L}$ devil's.head
b. Jou stommerik!
$\mathrm{You}_{\mathrm{ACC} / O B L}$ fool
c. Jou vark!
$\mathrm{You}_{\mathrm{ACC} / O B L}$ pig
(dialects of Waterland; Van Ginneken 1954)
(Afrikaans; Ponelis 1979)

But maybe the most remarkable form is the possessive pronominal one, as in Jespersen's (1977) example from Danish: dit foe! (your cattle ${ }_{\mathrm{sg}}$; 'you fool!'). Not unexpectedly, this pattern is also found in Norwegian (18) and Swedish (19):
(18) Din tosk!
your fool
'You fool!'
(19) Din lymmell!
your rascal
'You rascal!'
(Norwegian)
(Swedish)

This possessive vocative pattern is also attested in (variants of) Frisian (cf. (20); Jarich Hoekstra, p.c.). As shown in (21), it also exists in a variety of southern Dutch dialects.
a. Din letj skitjding! your little shitboy
'You little swine!'
b. Dan grute slüngel! yourbig rascal
'You big nasty boy!'
c. Dän tiif! your thief
'You thief!'

(Fering-Öömrang)

(Mooring)

(Wiedingharder Frisian)

(21) a. Jouwen deugniet! your rascal

'You rascal!'
b. Jouwen dikzak! your fatman
'You fatman!'

(Southern Dutch dialects; Kern 1927) 
This possessive vocative pattern is not only found in Germanic languages/ dialects. A language like Brazilian Portuguese, for example, also has this vocative pattern (Jairo Nunes, p.c.):
a. Seu idiota! your masc.sg idiot
'You idiot!' (where the addressee is a man)
b. Sua idiota! your fem.sg idiot
'You idiot!' (where the addressee is a woman)
c. Seus idiotas!
your ${ }_{\text {masc.pl }}$ idiots
'You idiots !' (where the addressees are men)
d. Suas idiotas!
your $_{\text {fem.pl }}$ idiots
'You idiots !' (where the addressees are women)

The three different appearances of the you idiot!-construction obviously raise the question as to whether the three patterns, which are similar as regards the linear ordering of the pronoun and the epithet noun, should be assigned a uniform syntactic analysis. I will return to this issue in Sections 6, 7, and 8.

\section{Some first remarks on the internal syntax: you idiot! versus we linguists}

In this section, I will make some initial remarks about the syntax of the evaluative vocative expression by comparing it with a nominal construction that also features a juxtaposition of a pronominal element and a noun, viz. the we linguistsconstruction. $^{11}$

The Dutch vocative pattern jij idioot! ' $\mathrm{you}_{\mathrm{NOM}}$ idiot', and its English equivalent you idiot!, is superficially similar to the noun phrase wij/jullie taalkundigen (English: we/you linguists) in sentences like (23): a pronoun combines with a lexical noun.

(23) a. [Wij/jullie taalkundigen] denken te veel na.
Welyou linguists think too much PRT
b. [We/you linguists] think too much.

The latter construction has been assigned a structure like (24), with wij as the D-head of the DP-projection, which takes the NP taalkundigen as its complement (cf. Postal 1966; Abney 1987). ${ }^{12}$

$\begin{array}{lll}\text { (24) } & \text { a. } & {[\mathrm{DP}[\mathrm{D} \text { wij/jullie] [NP taalkundigen }]} \\ & \text { b. } & {[\mathrm{DP}[\mathrm{D} \text { we/you }][\mathrm{NP} \text { linguists }]}\end{array}$

\footnotetext{
${ }^{11}$ See also Potts and Roeper (2006) for a comparison of these two types of constructions.

${ }^{12}$ See Déchaine and Wiltschko (2002) for a similar analysis. They assume that first and second person pronouns can function as determiners; third person pronouns cannot. They further assume that the DP contains an extra functional layer $\Phi \mathrm{P}$, where $\varphi$-features are encoded: [DP [D we [ФP $\Phi$ [NP linguists]]]]. 
On the basis of this superficial similarity, one might want to argue that the vocative expression jij idioot!/you idiot! should also be assigned a structure like (24). Thus:
a. [DP [D jij] [NP idioot]]
b. [DP [D you $][\mathrm{NP}$ idiot $]$

There are reasons, however, for saying that expressions like you idiot! should not be treated on a par with nominal constructions of the type we linguists. The two nominal constructions turn out to display different syntactic behavior. First of all, as opposed to the vocative you idiot(s)! construction, the pronominal part of the we linguists construction cannot be singular: ${ }^{13}$

(26) a. I think that [you linguists] think too much.

b. $\quad *$ I think that [you linguist] think too much.

(27) a. Ik denk dat [jullie taalkundigen] te veel nadenken. (Dutch)

b. $\quad *$ Ik denk dat [jij taalkundige] te veel nadenkt.

Second, the we linguists-construction appears as an argumental noun phrase [see (28a) and (29a)], whereas the you idiot!-construction does not [see (28b) and (29b)]; see also Potts and Roeper (2006) for this observation. The latter construction typically functions as a 'clause-independent' (vocative) expression:
a. I believe that [you linguists] work too hard.
b. $\quad$ *I believe that [you idiot] work too hard!
a. Ik geloof dat [jullie taalkundigen] te hard werken. (Dutch)
b. $\quad$ *Ik geloof dat [jij idioot] te hard werkt!

\begin{abstract}
${ }^{13}$ As observed by Déchaine and Wiltschko (2002), the first person singular pronoun and the third person singular and plural pronouns cannot combine with a lexical noun either: *I linguist, *he linguist, *they linguists. I have no account for the impossibility of these combinations in English. In present-day Dutch, these combinations are also ruled out: *ik taalkundige, *hij taalkundige, *zij taalkundigen. Interestingly, in seventeenth century Dutch, these combinations were possible (see Koelmans 1978): e.g., zy vrouw (she NOM $_{\text {woman), hij graef (he }} \mathrm{NOM}_{\mathrm{M}}$ earl), sy gesanten (they $\mathrm{NOM}_{\mathrm{M}}$ envoys), met hem lieutenant (with him $\mathrm{OBL}_{\mathrm{O}}$ lieutenant). As pointed out by a reviewer, similar patterns are also attested in present-day Danish, Norwegian and Swedish [see e.g., (i) and (ii)]. In those examples, the third person singular [+human] pronoun is used as a demonstrative (see Julien 2005 and Johannessen 2006 for discussion). In Swedish and Norwegian, the pronoun appears in the nominative in this construction type, while Danish uses the accusative.
\end{abstract}

(i) [Han killen] ringed till mej mitt i natten.

(Swedish)

He guy-def rang to me middle in night

'That guy called me in the middle of the night.'

(ii) $\quad$ Hende pigen $]$ gad ikke noget alligevel.
Her girl.def bothered.to not anything after.all

(Danish)

'The girl/that girl could not be bothered to do anything after all.' 
In (28b) and (29b), the second person singular pronoun is used in order to force a vocative pattern, that is, you idiot!. Remember that the we linguists-construction is excluded with the second person singular [cf. (26b) and (27b)].

The same contrast between the vocative you idiot!-construction and the we linguists-construction is found in languages displaying a possessive pronoun in the former construction. This is exemplified in (30) for Brazilian Portuguese (Jairo Nunes, p.c.). (30) shows that 'we/you linguists' can occur as an argument; (31) shows that the vocative phrase seus idiotas! 'you idiots!' is excluded in that position.

(30) a. [Nós linguïstas] pensamos demais.

We linguists think too.much

b. [Vocês linguïstas] pensam demais.

You $_{p l}$ linguists think too.much

*[Seus idiotas] pensam demais!

Your idiots think too.much

The following examples from Swedish, which, just like Brazilian Portuguese, feature a possessive pronoun in the evaluative vocative expression, also illustrate the non-occurrence of vocative expressions in argumental positions (Lars-Olof Delsing and Ylva Falk p.c.):
a. *[Din idiot] borde vara försiktigare $\quad \mathrm{i}$ framtiden. Your idiot should be careful-COMPAR in future.the
b. *[Din fuling] ska inte stjäla min grammatik.
Your idiot shall not steal my grammar.book
c. *Jag ska träffa [din idiot] på restaurangen.
I will meet your idiot in restaurant.the

Importantly, the possessive vocative pattern is permitted when it occurs as an appositive of the second person pronoun: ${ }^{14}$
a. [Du, din idiot,] borde vara försiktigare i framtiden.
You, your idiot, should be careful-COMPAR in future.the
b. [Du, din fuling, ] ska inte stjäla min grammatik.
You, your idiot, shall not steal my grammar.book
c. Jag ska träffa [dig, din idiot,] på restaurangen.
I will meet you, your idiot, in restaurant.the

\footnotetext{
${ }^{14}$ The same holds for Brazilian Portuguese. Compare the ill-formed example (31) with the well-formed example (i):

(i) [Vocês, [seus idiotas]], pensam demais!

You, your idiots, think too.much

'You, you idiots, think too much!' 
As shown in (34), this appositive occurrence of the vocative expression is also found in English and Dutch. ${ }^{15}$

(34) a. I believe that you, you stupid idiot, work too hard! (compare with (28b))

b. Ik geloof dat jij, jij stomme idioot, te hard werkt! (compare with (29b))

On the basis of the phenomena discussed in this section, I conclude that the vocative you idiot!-construction should not be treated on a par with the we linguistsconstruction, which is generally analyzed as an instantiation of the structural pattern:

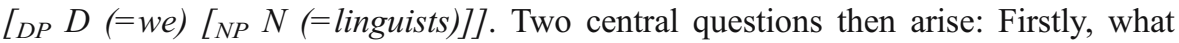
exactly is the internal syntax of the you idiot!-construction? Secondly, how do we account for the variation in the formal appearance of the pronominal part? Those two questions will be addressed in fair detail in what follows. There is a third question, though, that also comes to the fore in the present section, namely: Why is it that the you idiot!-construction is confined to vocative/non-argumental contexts, whereas, for example, the we linguists-construction and other nominal constructions such as the $N$ of $\mathrm{N}$-construction and the DP-internal possessive construction are not. ${ }^{16}$ Although this question does not belong to the core part of this article, I will present some thoughts on this issue as well in what follows.

\section{Towards a predicate displacement analysis}

Recall from Section 1 that Jespersen had the intuition that constructions such as the city of Rome, a devil of a fellow, pobrecitos de nosotros had a certain similarity as regards the structural relationship between the two elements linked by of/de. From the perspective of current generative syntactic theorizing on these constructions, we might characterize this similarity in terms of the notions 'predication' and 'DPinternal predicate displacement': the first lexical category ( $\mathrm{N}$ or $\mathrm{A}$ ) acts as a predicate nominal and predicates over the noun that follows. If the predication relation starts out with a subject-predicate order, then the word order 'predicatesubject' is a derived one, obtained by predicate displacement within the noun phrase. If we extend this analysis to the Danish vocative phrase dit foe!, observed by

\footnotetext{
15 The second person pronoun in the appositive noun phrase can easily be left out, as the reference to a second person (i.e., the addressee) is contextually given. As pointed out to me by a reviewer, dropping the (possessive) pronoun in the appositive phrase is much harder in Scandinavian: e.g., Swedish [du, *(din) dumma idiot!]. A Google search by the reviewer yielded two relevant hits, both being exclamations [see e.g., (i)]. A search for the pattern $d u$, din dumma idiot yielded numerous hits.
}

(i) ..., o ack du dumma idiot. $\quad$ (Swedish)
..., alas you stupid idiot

${ }^{16}$ As already suggested in Section 1 and as will be discussed more elaborately in what follows, the internal syntax of you idiot! will be assimilated almost fully to that of DP-internal possessives. Given this, it appears that the fact that you idiot! is restricted to vocative/non-argumental contexts is not something that can be derived from its internal syntactic constitution. 
Jespersen, we have another instance of DP-internal predicate displacement. In what follows, I will explore this predicate displacement analysis also for the other manifestations of the evaluative vocative expression that I introduced in Section 3. In order to make the reader more familiar with the phenomenon of DP-internal predicate displacement, I will first briefly discuss some recent proposals regarding the operation of predicate displacement, and more particularly the one made in Den Dikken (1995; 2006).

\subsection{Predicate displacement and the nominal copula 'of'}

In recent generative studies, a number of nominal construction types have been (re) analyzed in terms of predicate displacement, most notably the so-called $N$ of/de $N$-construction [cf. (2)]. Kayne (1994, p. 106) proposes an analysis according to which amour originates as a clause-internal predicate and is preposed (across the subject enfant in Spec,IP) to the specifier position of a clause headed by a prepositional determiner de (comparable to a prepositional complementizer in the clausal domain).

\section{[un [D/PP [NP amour $\left.r_{\mathrm{j}}\right]\left[\mathrm{de}\left[\mathrm{IP}\right.\right.$ enfant $\left.\left.\left.\left.\mathrm{I}^{\mathrm{O}}[\mathrm{e}]_{\mathrm{j}}\right]\right]\right]\right]$}

An alternative implementation of the DP-internal predicate displacement analysis is given by Den Dikken (1995; see also Den Dikken 2006). He proposes that in constructions like (2), the displaced predicate originates in a DP-internal small clause configuration [XP in (36)] and raises across the small clause subject to the Specposition of a higher functional head FP (cf. also Bennis et al. 1998 for discussion). ${ }^{17}$ Schematically: ${ }^{18}$

\section{[DP that $\left.\left[{ }_{F P} i_{d i o t}\left[{ }_{\mathrm{F}}, \mathrm{F}(=\mathrm{of})+\mathrm{X}_{\mathrm{i}}(=\mathrm{a})\left[\mathrm{XP} \operatorname{doctor}\left[\mathrm{x}, \mathrm{t}_{\mathrm{i}} \mathrm{t}_{\mathrm{j}}\right]\right]\right]\right]\right]$}

According to Den Dikken, predicate movement as found in (36) is taken to be an A-movement operation (termed 'Predicate Inversion'). ${ }^{19}$ What characterizes this movement operation is that the inverted nominal predicate skips an intermediate A-position, viz. that of the small clause subject (i.e., doctor). Hence, the movement of the nominal predicate appears to be a non-local A-movement. As Den Dikken (1995) points out, however, the predicate movement is local if one adopts Chomsky's (1993) locality theory in terms of equidistance. Under this theoretical proposal, the moved predicate can cross the subject as long as the two nominals are technically equally far away from the predicate's extraction site. Under Chomsky's assumptions, this situation is obtained by the application of a domain-extending head

\footnotetext{
${ }^{17}$ In Den Dikken (2006), XP is referred to as RP (i.e., Relator Phrase). The Relator-head mediates the predication relationship between the subject and the predicate.

18 The lexical item $a$ is the so-called spurious definite article, which according to Bennis et al. (1998) originates in the head position of a DP-internal small clause (XP). See Section 6 for a more elaborate discussion of this grammatical element.

${ }^{19}$ In Bennis et al. (1998), A-type predicate displacement is referred to as Predicate Inversion. A-bar type predicate displacement is called Predicate Fronting.
}

Springer 
movement operation that creates a minimal domain that contains both the raised predicate and the small clause subject. Den Dikken (1995) argues that in the case of DP-internal predicate inversion, the requisite domain extending head-movement operation consists of raising of the functional head $(\mathrm{X})$ of the small clause to a higher functional head (labeled here as ' $F$ '). ${ }^{20} \mathrm{He}$ further claims that the element de/of is a nominal copula, which surfaces at $\mathrm{PF}$ as a result of $\mathrm{X}$-to-F raising; in fact, this nominal copula is considered to be the (nominal) equivalent of the verbal copula to be, which obligatorily appears in predicate inversion structures in the clausal domain (e.g., I consider the best candidate *(to be) John); cf. Moro (1991). ${ }^{21}$

\subsection{The nominal copula $-\mathrm{s}$ in possessive constructions}

In Den Dikken (1998), it is argued that DP-internal predicate displacement also applies within possessive noun phrases like John's car, which features the 'linking' element's, that is, the bound morpheme that is traditionally referred to as the Saxon genitive (see also Corver 2003). Rather than interpreting this element as a clitic or affix-like element base-generated in a functional head position (say, D or Agr), Den Dikken proposes that's should be interpreted as another instantiation (i.e., PF-spell-out) of the nominal copula that surfaces in contexts of DP-internal Predicate Inversion. The derivation that underlies a construction like John's car is represented in (37):

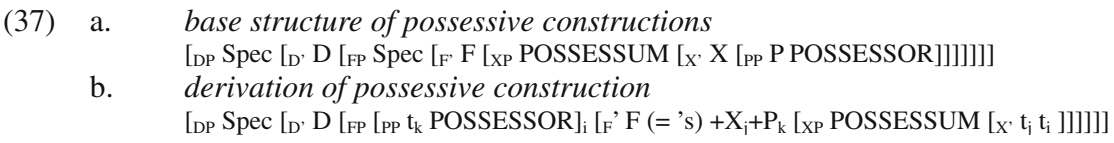

(37a) represents the source structure in which the possessor ( John) is contained in a prepositional predicate (i.e., PP), which is headed by a dative assigning null preposition (i.e., $\mathrm{P}_{\varnothing}$ ) and which takes the possessum (car) as its subject. ${ }^{22}$ Thus, the

\footnotetext{
${ }^{20}$ In Den Dikken (2006, p. 112 ff.), the issue of locality (i.e., equidistance) in predicate movement configurations is reconsidered from the perspective of Chomsky's (2001) phase theory. The (DP-internal) small clause (say, XP) is propositional and, as such, qualifies as a phase. Given the Phase Impenetrability Condition (Chomsky 2001), the complement of the small clause head X is not accessible to operations outside XP (i.e., only the edge (i.e., Spec) position and the (small clause) head are accessible to operations outside XP, e.g., an Agree relationship with a higher functional head F). As a consequence of this, the predicate that occupies the complement position of the small clause head $\mathrm{X}$ is not visible to an outside probe (say, F). As Den Dikken (p. 115) points out, one way of making the predicate accessible to a functional head (a probe) outside the small clause-phase (XP) is 'phase extension': i.e., movement of the head of a phase to a higher head F extends the phase to FP. I refer the reader to Den Dikken (2006) for further discussion of predicate movement within a phase-based theory. For the purposes of this paper, I will leave the implementation of locality in terms of phase theory outside of my analyses of the various vocative expressions.

${ }^{21}$ In copular constructions with a straight subject-predicate order, the appearance of the verbal copula is not obligatory:

(i) I consider John (to be) the best candidate.

22 In certain languages, this 'underlying' possessum-possessor pattern surfaces, as in French un livre à Jean (a book to Jean; 'Jean's book'); see Kayne (1994) and Den Dikken (1998) for discussion.
} 
'underlying' possessive meaning roughly corresponds to: 'car (is) to John'. (37b) represents the structure that is derived by: (1) the application of X-to-F-movement (for reasons of domain extension (equidistance)), (2) incorporation of $\mathrm{P}$ into the F-complex (yielding the possessive 'have'-relation at the nominal level), (3) predicate displacement of the "beheaded" dative PP across the possessum to Spec,FP.

Notice that this analysis of the DP-internal possessive relationship draws a parallel with recent analyses of possessive have-constructions (as in: John has a car), according to which, in line with Benveniste's (1966) original insight, the possessive have construction derives from the be + to construction (cf. Freeze 1992; Kayne 1994). ${ }^{23}$ In Den Dikken's $(1998,2006)$ implementation of Benveniste's original idea, a possessive clause like John has a car has (38a) as its 'underlying' structure and (38b) as its derived structure:

(38) a. [IP Spec [I' I [FP Spec [F, F [XP a car [x, X [pp $P_{\text {dative }}$ John] ] ] ] ]

b. [IP Spec [I, I [FP [PP $\left.\mathrm{t}_{\mathrm{k}} \mathrm{John}\right]_{\mathrm{j}}\left[\mathrm{F}, \mathrm{F}+\mathrm{X}_{\mathrm{i}}+\mathrm{P}_{\mathrm{k}}(=\right.$ has $)$ [XP a car $\left.\left.\left.\left.\left.\left[\mathrm{X}, \mathrm{t}_{\mathrm{i}} \mathrm{t}_{\mathrm{j}}\right]\right]\right]\right]\right]\right]$

In (38a), the possessor (John) starts out as the complement of a dative preposition and the possessum ( $a$ car) as the subject of the small clause. The possessive HAVEconstruction is derived by incorporation of $\mathrm{P}$ out of the dative PP (i.e., the predicate) into the copular verb BE, which results from X-to-F movement, with subsequent Predicate Inversion of the beheaded dative PP to Spec,IP; see (38b). ${ }^{24}$

\subsection{The nominal copula -s in adjectival contexts}

If $o f / d e$ and $-s$ are copulas that surface in nominal (i.e., $[+\mathrm{N}]$ ) environments, one might expect them to also be present in adjectival structures. In Corver (2000), it is argued that a Rumanian adjective phrase like extrem de inalt (extreme of tall; 'extremely tall') features predicate displacement (more specifically, Predicate Inversion) of the degree designating element extrem across the gradable 'subject'AP inalt:

$\left[\mathrm{FP}\right.$ extrem $_{\mathrm{j}}\left[\mathrm{F}, \mathrm{F}(=\mathrm{de})+\mathrm{X}_{\mathrm{i}}\left[\mathrm{XP}\right.\right.$ înalt $\left.\left.\left.\left[\mathrm{x}, \mathrm{t}_{\mathrm{i}} \mathrm{t}_{\mathrm{j}}\right]\right]\right]\right]$

${ }^{23}$ The possessive be + to pattern surfaces in a language like French [cf. (ia)]. French also permits the possessive 'have' pattern [cf. (ib)].

(i) a. Le livre est à Pierre.

The book is to Pierre

b. Pierre a le livre.

Pierre has the book

24 The verbal form HAVE (i.e., F + X + P) raises to I to pick up/check its Tense property.

Springer 
Interestingly, in late nineteenth and early twentieth century Dutch we find adjectival constructions of the type in (40) (cf. Royen 1948, p. 342):
a. ...alhoewel dat [dekselkaters lastig] aan me vallen zal
...although that cover+tom-cat-s difficult to me fall will '....although that will be deucedly difficult for me'
b. Ben jij die jongen die [zoo bliksems mooi] kan teekenen Are you that boy who so lightning-s beautifully can draw 'Are you that boy who can draw so bloody/devilishly well' It was distorted(s) tasty 'It was deucedly tasty'
c. Het was [verdraaid $(s)$ lekker]

And also in present-day Dutch, we run into adjectival expressions like: stervens-benauwd (die-s-sultry; 'very sultry'), dood-s-bang (death-s-afraid, 'very afraid'), hond-s-brutaal (dog-s-impudent; 'very impudent'), bliksem-s-goed (thunder-s-good; 'very well'), mieter-s-lastig (damned-s difficult; 'very difficult'), deksel-s-mooi (deuced-s beautiful;'very beautiful'), drommel-s-heet (deuced-s hot; 'very hot'), hels-koud (hell-s-cold; 'very cold'). In all of these expressions, the degree denoting element and the gradable adjective are separated from each other by an intervening 'linking' element $-S$, which, in view of the parallelism with the Rumanian adjectival construction in (39), I analyze as a nominal copula, that is, the surface reflex of the presence of $\mathrm{F}$ in predicate inversion environments. The derived structure of an adjectival expression like duivels aardig (devil-s kind; 'very kind') then looks as follows:

$$
\begin{aligned}
& \text { [FP duivel } \left.{ }_{\mathrm{j}}\left[\mathrm{F}^{\prime} \mathrm{F}(=-s)+\mathrm{X}_{\mathrm{i}}\left[\mathrm{XP} \operatorname{aardig}\left[\mathrm{X}^{\prime} \mathrm{t}_{\mathrm{i}}\left[{ }_{\mathrm{AP}} \mathrm{t}\right]_{\mathrm{j}}\right]\right]\right]\right] \\
& \text { devil }-s \quad \text { kind } \\
& \text { 'very kind' }
\end{aligned}
$$

In the Dutch examples given above, the degree-designating element is nominal in nature. It is a noun (e.g., duivel 'devil'; bliksem 'lightning') or a nominal form of the verb (i.e., a participle [e.g., verdraaid 'distorted'] or an infinitive [e.g., sterven '(to) die']). Interestingly, some of these nominals also appear as modifiers within noun phrases: ${ }^{25}$
a. die hel-s-e pijnen
those hell-s-e pains
'those hellish pains'
b. die duivel-s-e kerel
that devil-s-e man
'that devilish man'
c. die bliksem-s-e jongens
those lightning-s-e boys
'those bloody boys'

\footnotetext{
${ }^{25}$ As pointed out to me by Aniko Liptak, Hungarian also permits epithets in possessive forms (only in the third person singular): e.g., a disznója (the pig-poss.3sg; '(he), the pig'); az állatja (the animal-poss.3sg; '(he) the animal'); a hülyéje (the stupid-poss.3sg; '(he) the idiot'). In these examples we arguably deal with an adjective. These adjectival forms seem to have a lexicalized status.
} 
Traditionally, the element $-s$ is interpreted here as a derivational suffix that turns a noun into an adjective. The $-e$ (schwa) that follows the sequence Noun $+s$ is the inflection that shows up on attributive adjectives in Dutch. In the spirit of the DPinternal predicate displacement analysis as defended here, I would like to propose that in those constructions also, $-s$ is a nominal copula. Drawing a parallel with the Dutch $N$ van $N$-construction [cf. (43)], this would lead us to a derived structure like (44):

$$
\begin{aligned}
& \text { [DP die [FP duivel } \left.\left.{ }_{j}\left[{ }^{\prime}, F(=\operatorname{van})+X_{i}(=' n) \text { [XP jongen }\left[\mathrm{x}^{\prime} \mathrm{t}_{\mathrm{i}} \mathrm{t}_{\mathrm{j}}\right]\right]\right]\right] \\
& \text { that devil of } a \text { boy } \\
& \text { [DP die } \left.\left[F P \text { duivel }{ }_{j}\left[F, F(=-s)+X_{i}(=-e) \text { [XP jongen }\left[x, t_{i} t_{j}\right]\right]\right]\right]
\end{aligned}
$$

As indicated in structure (44), I (tentatively) assume that the Dutch inflectional element $-e$, which appears on attributively used adjectives, is the surface reflex of the raised small clause head $X{ }^{26}$ In its base position, $\mathrm{X}$ stands in a spec-head relation with the subject of the small clause [i.e., the [-neuter], [+singular] nominal phrase jongen in (44)]. Let's assume that the small clause head X stands in an agreement relation with the subject nominal in $[\mathrm{Spec}, \mathrm{XP}]$, and that after adjunction of $\mathrm{X}$ to $\mathrm{F}, \mathrm{X}$ surfaces as the attributive inflectional morpheme $-e$ (cf. Corver 2004). ${ }^{27}$

Some other constructions featuring the (bimorphemic) element -se (i.e., nominal copula $-s+$ adjectival inflection $-e$ ) are given in (45) and (46). The examples in (45) are taken from the dialect of the Kempenland (De Bont 1958). The element -se attaches to a measure-denoting nominal. ${ }^{28}$ The example in (46) is taken from the

\footnotetext{
${ }^{26}$ The attributive adjectival inflection $-e$ does not appear on Dutch attributive adjectives modifying indefinite neuter singulars. Those take a zero-morpheme, as in: een hel-s-ø karwei (a hell-s-ø job; 'a hell of a job').

${ }^{27}$ In Bennis et al. (1998), it is argued that there is an agreement relationship between the so-called spurious indefinite article - which is taken to be the small clause head X - and the subject of the small clause. In a language like English, the small clause head $a$ in that idiot of a man is specified as [-PL] and hence can only co-occur with a [-PL] small clause subject, given the specifier-head agreement relationship within XP. Schematically:
}

(i)

$$
\begin{array}{ll}
\text { a. } & {\left[\operatorname{XP}_{[-P L]}\left[\mathrm{x}, \mathrm{a}_{[-\mathrm{PL}]} \text { idiot }\right]\right]} \\
\text { b. } & {\left[\mathrm{DP} \text { that }\left[\mathrm{FP} \operatorname{idiot}_{\mathrm{j}}\left[\mathrm{X}, \mathrm{F}(=o f)+\mathrm{X}\left(=a_{[-\mathrm{PL}]}\right)\left[\operatorname{man}_{[-\mathrm{PL}]}\left[\mathrm{X}, \mathrm{t}_{\mathrm{i}} \mathrm{t}_{\mathrm{j}}\right]\right]\right]\right]\right.}
\end{array}
$$

It is further argued in that article that the spurious indefinite article in Dutch is unspecified for number. This renders the small clause head X (i.e., een) compatible with any NP in its specifier, regardless of the latter's number specification. This accounts for the fact that spurious een can be followed, for instance, by a plural noun, as in die idioten van een jongens (those idiots of a boys; 'those idiots of boys'). See Section 6 for further discussion.

${ }^{28}$ In Standard Dutch, the sequence M(easure) $P($ hrase $)+-$ se + noun is not permitted. Instead, we find a nominal construction in which MP is part of a van-phrase, as in (i):

(i)

$$
\begin{aligned}
& \text { a. een fles van een liter } \\
& \text { b. } \quad \text { een snoek van een pond } \\
& \text { a pike of a pound }
\end{aligned}
$$


dialect of Helmond (Weijnen 1966, p. 312). ${ }^{29}$ In this example, $-s e(n)$ attaches to a masculine singular possessor noun phrase. ${ }^{30}$

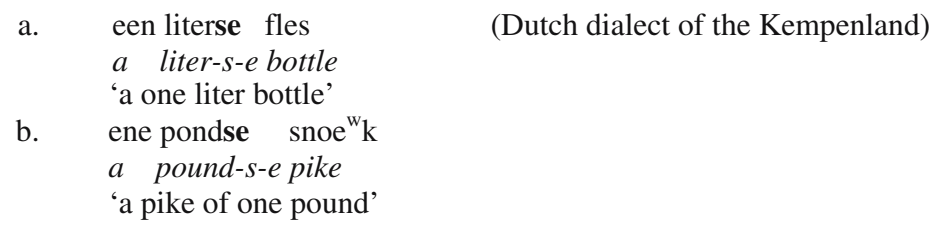
vadersen hond Masc.sg. $_{\text {. }}$ father-s-en dog
(Dutch dialect of Helmond)
'father's dog'

If we adopt, analogously to (44), a predicate displacement analysis for these nominal constructions, the following derived representations can be assigned to them:

$$
\begin{array}{ll}
\text { a. } & {\left[D P \text { een }\left[F P \operatorname{liter}_{j}\left[F, F(=-s)+X_{i}(=-e)\left[X P \text { fles }\left[x, t_{i} t_{j}\right]\right]\right]\right]\right]} \\
\text { b. } & {\left[D P D\left[F P \operatorname{vader}_{j}\left[F, F(=-s)+X_{i}(=-e n)\left[X P \text { hond }\left[X, t_{i} t_{j}\right]\right]\right]\right]\right]}
\end{array}
$$

To summarize: along the lines of Den Dikken (1998, 2006), I have argued that the 'possessive' marker $-s$ should be treated as a nominal copula, which shows up in contexts of predicate inversion. The inflectional element $-e$ was taken to be the spellout of the small clause head X that agrees with the small clause subject in [Spec,XP] and adjoins to $\mathrm{F}$, creating the sequence $-s-e$.

\footnotetext{
${ }^{29}$ In the traditional dialectology literature (cf. Weijnen 1966, p. 312), the patterns in (46) are referred to as 'inflected genitives'. Interestingly, these patterns also occur in child language (see Van Kampen and Corver 2006 for discussion):
}

(i) $\quad$ a. $\quad$ Stijn-tje-se moeder $]$ kwam ons halen

(Dutch child language, 6;7.14)

Stijntje-se mother came us get
b. Iedereen vindt [z'n mama-se kusjes] het lekkerste

everybody considers his mommy-se kisses the best

(Dutch child language, 5;5.4)

${ }^{30}$ When the possessum is feminine singular, there is no phonologically overt affix following $-s$ that formally expresses the agreement relationship between the possessor and the possessum. For example:

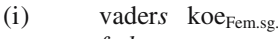

father-s cow

'father's cow' 


\section{The pattern 'second person pronoun $+s e+$ epithet noun'}

\section{1 'O doe se stommerik!'}

My discussion of the nominal construction die duivelse jongen brings us back to the topic of this paper, viz. the syntax of the you idiot!-construction. More particularly, it brings us to a discussion of a variant of the you idiot!-construction, which superficially at least is very similar to a phrase like die duivelse jongen but which, as I will argue, differs in a subtle way from this construction. Consider the examples in (48), which are taken from the dialect of Aarschot (Belgium, province of Brabant) and were first discussed in Pauwels $(1940,1958) .{ }^{31}$

$\begin{array}{ll}\text { (48) a. } & \text { O doe se stommerik! } \\ & \text { Oh you se idiot } \\ & \text { Oh, you idiot!' } \\ \text { b. } & \text { Doe sen ezel! } \\ & \text { You se donkey } \\ & \text { You donkey!' }\end{array}$

These constructions exemplify the following surface pattern: Optional interjection + second person pronoun $+s e(n)+$ noun. The pronominal form doe is the old second person singular subject form. ${ }^{32}$ Pauwels (1958, p. 339) notes that the use of this pronominal form is restricted to the vocative patterns in (48). Thus, doe is no longer used in clausal subject positions. In those positions, the pronominal form gij (you, second person singular) is used. As shown in (49), the form gij is also found in the evaluative vocative expression under discussion here:
a. Gij sen deugniet!
You se rascal
'You rascal!'
b. $\quad \mathrm{O}$ Gij se stommerik!
Oh you se idiot
'Oh you idiot!'

\footnotetext{
${ }^{31}$ Pauwels (1940, p. 201) argues that the element se(n) is found in Flemish Brabant, Antwerp, and the western part of (Belgian) Limburg.

${ }^{32}$ Compare with German $d u$ (you NOM ), as in: Du bist krank 'You are ill'.

Springer
} 
As exemplified in (50), an attributive adjective can occur in between $s e(n)$ and the epithet noun (examples drawn from Pauwels 1940, 1958): ${ }^{33}$
a. Doe se lelijk-en $\operatorname{dief}_{\text {Masc }}$ !
You se ugly thief
'You ugly thief!'
b. $\quad \mathrm{O}$ doe se smerig-e teef!
Oh you se dirty bitch $_{\text {Fem }}$
'You dirty bitch!'
c. O doe se kwaad kind Neut $_{\text {! }}$ ?
Oh you se angry child
'You angry child!'
d. O doe se vuil kinderen!
Oh you se dirty children Plural
'You ${ }_{\text {plur }}$ nasty children!'

Observe that se (modulo phonetically conditioned variation) is invariant in the above examples: its formal appearance is not determined by the phi-features of the epithet noun. Compare in this respect se with the attributive adjectives preceding the epithet noun. The attributive adjective agrees with the noun, which is manifested by the suffix -en before a masculine singular noun (50a), $-e$ before a feminine singular noun (50b), a zero-suffix before a neuter singular noun, and $-e$ before a plural noun. ${ }^{34}$ The absence of the plural suffix $-e$ after vuil in (50d) is due to a phonological rule which deletes $-e$ if the adjective ends in a long vowel or diphthong (Pauwels 1958, p. 310). The fact that se in (50) does not co-vary according to gender and number with the epithet noun suggests that it - more particularly, the element $-e-$ is not an adjectival inflection. ${ }^{35}$ The example which shows most clearly that there is no agreement relationship between $s e(n)$ and the head noun is $(50 \mathrm{c})$. If the element $-e$ in $s e(n)$ were an adjectival inflection, we would expect a form like $O$ doe $s$ kwaad kind!;

\footnotetext{
33 The adjectives in (50) are highly expressive themselves and arguably are not used with their literal interpretation. The adjective lelijk-en in (50a), for example, does not qualify the thief as being ugly physically. Thus, (50a) may be used by a speaker when he considers the thief to be a handsome person.

34 The $n$ of the masculine singular suffix -en is apocopated before all consonants, except before $s$ and $d$. Before $b$ and $r$, the $-n$ is optional. (cf. Pauwels 1958, p.310)

${ }^{35}$ But see below for some cases where $s e(n)$ does seem to be inflected.
} 
that is, the adjectival inflection should be null (compare with kwaad, which lacks a schwa). ${ }^{36}$

The element se does not seem to co-vary either with the possessive pronoun. It does not matter, for example, whether doe gets a singular interpretation [e.g., (50a)] or a plural interpretation [cf. (50d)]; the form se remains the same. ${ }^{37}$ As noted in Pauwels (1958, p. 413), se also sporadically appears after the third person demonstrative pronouns $d i$ ('that', masc. sg.) and $d \bar{l}$ (fem. sg.). From the fact that se combines both with second person pronouns and third person pronouns we may conclude that there is no agreement in person properties either.
a. Oh diə se lelijken dīf!
Oh that se ugly thief
'Oh you bloody thief!'
b. Oh dī se zwęte kroa!
oh that se black raven
'Oh you black raven!'

\subsection{The element se in West Flemish possessive noun phrases}

In view of the above considerations, it seems fair to conclude that in the above examples se(n) is not endowed with phi-features such as gender and number. In this respect, the element $s e(n)$ in the pattern $d o e+s e(n)+$ noun differs in a subtle way from the bimorphemic element $-s-e$ that we identified in nominal constructions such as die duivel-s-e jongen; see (44), where $-s$ was identified as the nominal copula and $-e$ as the attributive adjectival inflection. I would like to argue that the element se in the evaluative vocative expression doe se stommerik in (48a) is quite similar to the

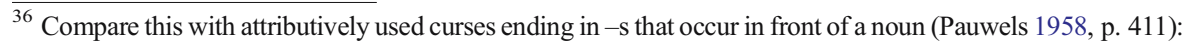

(i) a.

een nondedieu-s-e $\quad$ luiaard $_{[\text {masc }]}$

a god-damned-s-e sluggard

'a god damned sluggard'

b. Dat goddomme-s paard [neut] $_{\text {wil niet trekken }}$

That god-damned-s horse wants not pull

'That god damned horse does not want to pull.'

As shown in (ib), goddommes has no -e.

${ }^{37}$ Pauwels $(1958$, p. 121) also gives an example with the second person plural pronoun gijlie, which historically derives from gijlieden (you + people; ' $\mathrm{you}_{\mathrm{p} 1}$ ').

(i) gijlie se embêtanteriken you 2 p.pl. se teasers 
element se that Haegeman (2003a, b, 2004a, b) identifies in West Flemish possessive noun phrases like (52): ${ }^{38}$
a. $\quad$ Valère $_{\text {Masc }}$ se boek
'Valère's book'
b. Marie Fem $_{\text {se boek }}$
Marie se book
'Marie's book'

As Haegeman observes, se is used both for feminine and masculine possessors. It does not seem to be endowed with phi-features that match those of the possessor. In this respect the 'possessor se(n) possessum' construction in (52) differs from the

\footnotetext{
${ }^{38}$ In her discussion of the West Flemish possessive noun phrase Valère se boek, Haegeman (2003a, b, $2004 \mathrm{a}, \mathrm{b})$ makes the following observations as regards the behavior of $s e$ : First, se only combines with a singular possessor [cf. (ia)]; second, se is used both for feminine and masculine possessors [cf. (ib)]; third, the possessor and se must be adjacent [cf. (ic)]; fourth, the possessor cannot be remote from se, i.e., possessor and se seem to form a single word [cf. (id)]; fifth, se can appear with a reciprocal possessor [cf. (ie)].

(i) a. die student(*en) se boeken

those student(s) se books

'this student's/those students' books'

b. $\quad$ Valère $_{\text {masc }} /$ Marie $_{\text {fem }}$ se boek

Valère/Marie se book

'Valère's/Marie's book'

c. *Valère al se boeken (Compare: al Valère-se boeken)

Valère all se books

'all Valère's books'

d. *Wekken verpleegster zei-je gie dan-ze gisteren sen us verkocht een? Which nurse said-you you that-they yesterday se house sold have 'Who was the nurse whose house you said they sold yesterday?'

e. ...dan ze mekoar-se gasten gezien een ..that they each.other-se guests seen have
}

Haegeman points out that, with respect to the above-mentioned syntactic properties, the doubling possessive construction Valère zenen boek (Valère his book; 'Valère's book') behaves differently from the possessive construction featuring se.

(ii) $\quad$ a. $\quad$ Marie en Valère] under boeken

Marie and Valère their books

'Marie and Valère's books'

b. Valère zenen boek / Marie euren boek

Valère his book/Marie her book

'Valère's book' / 'Marie's book'

c. Valère al zen boeken (also: Al Valère zen boeken)

Valère all his books

d. Wekken verpleegster zei-je gie dan-ze gisteren eur us verkocht een? Which nurse said-you you that-they yesterday her house sold have 'Who was the nurse whose house you said they sold yesterday?'

e. *..dan ze mekoar under gasten gezien een ..that they each.other their guests seen have

Given these contrasts, it is quite clear that se should not be treated on a par with the pronominal element in the possessive doubling construction. 
West Flemish possessive doubling construction, which is exemplified in (53); cf. Haegeman (2003a, 2004a).
a. Valère
Valère.sg. zenen
Masc.sg. boek
'Valère's book'
b. $\quad$ Marie $_{\mathrm{Fem} . \mathrm{sg}}$ euren $\mathrm{Fem.sg}_{\text {. boek }}$
Marie her book
'Marie's book'

In this construction, a possessive pronoun occurs in between the possessor (Valère/Marie) and the possessum (boek). As indicated in (53), the phi-features of the 'linking' pronoun match those of the possessor.

On the basis of this contrast in agreement between the possessive pattern in (52) and the one in (53), Haegeman (2003a) concludes that se is not a pronominal element. In Haegeman (2003b), it is stated that se roughly corresponds to the English genitive marker (as in John's book/Mary's book) and is located in D (cf. also Corver 1990). This yields a structure like (54) for (52a):

[DP Valère [D' [D se] [NP boek]]]

\section{$6.3 \mathrm{Se}$ as a nominal copula}

With Haegeman (2003b), I will assume that the invariant element se(n) corresponds to the English 'genitival'/possessive marker. But rather than interpreting it as a functional head D, I will analyze it as a nominal copula, in line with Den Dikken's (1998) interpretation of the English marker. Under the assumption that the nominal copula $s e(n)$ appears in contexts of DP-internal Predicate Inversion, the derivation in (55) can be assigned to the $d o e+s e(n)+N$ construction: $^{39}$

\footnotetext{
a. base structure

[FP Spec [F, F [XP stommerik [X, X (= $\varnothing)\left[\mathrm{PP} \mathrm{P}_{\varnothing}\right.$ doe $\left.\left.\left.]\right]\right]\right]$

b. derived structure

$\left[{ }_{\mathrm{FP}}\left[{ }_{\mathrm{PP}} \mathrm{t}_{\mathrm{k}}\right.\right.$ doe $_{\mathrm{j}}\left[\mathrm{F}{ }^{\prime} \mathrm{F}(=-\mathrm{se})+\mathrm{X}_{\mathrm{i}}(=\varnothing)+\mathrm{P}_{\mathrm{k}}\left[\mathrm{XP}\right.\right.$ stommerik $\left.\left.\left.\left[\mathrm{X}^{\prime} \mathrm{t}_{\mathrm{i}} \mathrm{t}_{\mathrm{j}}\right]\right]\right]\right]$
}

\footnotetext{
39 'ø' stands for 'phonetically empty'.

㩏 Springer
} 
As indicated by those structures, I assume that the predicate is prepositional (i.e., a PP). More particularly, in view of the possessive (i.e., 'have') relationship between the second person pronoun (doe) and the other noun (stommerik) - that is, '(the property of being an) idiot is to you' - I take it that the (inverted) predicate is a PP headed by a phonetically empty $\mathrm{P}$. The representation in $(55 \mathrm{~b})$ is obtained by a number of displacement operations: (1) movement of the small clause head $\mathrm{X}$ to $\mathrm{F}$ for reasons of domain extension (it is this movement operation that triggers the appearance of the nominal copula se); (2) incorporation of the preposition into the F-complex; (3) inversion of the beheaded PP to [Spec,FP].

I will assume that after incorporation of the (dative) null preposition has taken place, $\mathrm{P}$ is no longer able to assign (dative) case to the possessor. The pronominal element receives a subject (nominative) form: doe/gij, quite analogously to the appearance of the nominative form on the noun phrase of the inverted PP-predicate in possessive have-clauses; see (56a), with (56b) as its derived representation. I will assume here that the nominative/subject form [doe in (48), gij in (49), and he in (56)] should be interpreted as absence of case; that is, it is not a case that is assigned/ checked by some head in its structural environment; cf. Neeleman and Weerman (1999). ${ }^{40}$

$$
\begin{aligned}
& \text { a. } \mathrm{He}_{\text {<subject form }>\text { has a book. }} \\
& \text { b. } \quad\left[\mathrm{IP}\left[\mathrm{PP} \mathrm{P}_{\mathrm{k}} \text { he }\right]_{\mathrm{j}}\left[\mathrm{I}, \mathrm{P}_{\mathrm{k}}+\mathrm{I}(=\text { has })\left[\mathrm{XP} \text { a book }\left[\mathrm{X}, \mathrm{t}_{\mathrm{j}}\right]\right]\right]\right]
\end{aligned}
$$

\subsection{Some remarks on the external distribution of evaluative vocative expressions}

In the previous subsection, I argued that the expression doe se stommerik! involves an underlying predicative relationship, that is, '(the property of being an) idiot is to you'. This (informal) paraphrase of the meaning actually suggests that the noun

\footnotetext{
${ }^{40}$ As is well known from Szabolcsi's $(1983,1994)$ seminal work on the syntax of Hungarian possessive noun phrases, Hungarian also permits nominative possessors [cf. (i)] within the noun phrase. The nominative possessor typically follows the definite article. Besides this pattern, Hungarian permits DPinternal possessors carrying dative case. Those possessors typically precede the definite article [see (ii)] and can be extracted from within the noun phrase. The dative case might be analyzed in terms of the presence of an underlying (dative assigning) preposition; the nominative case might be interpreted as an instance of 'lack of case'. See Den Dikken (1998) for a discussion of Hungarian possessive noun phrases from the perspective of DP-internal predicate movement.
}

(i) (a) Mari kalap-ja-i

(the) Mari-NOM hat-POS-PL(-3SG)

'Mari's hats'

(ii) Mari-nak a kalap-ja-i

Mari-DAT the hat-POSS-PL(-3SG)

'Mari's hats' 
stommerik 'idiot' is also taken to be a property-denoting noun, that is, a predicate. ${ }^{41}$ The question, therefore, arises as to what it is predicated of. ${ }^{42}$ One might be tempted to say that stommerik is predicated of the D-head of the DP dominating the entire you idiot!'-construction à la Williams (1981). But for Williams, the (referential) role $\mathrm{R}$ that is being assigned by the determiner is for referentiality, and referentiality may be precisely something that the vocative/non-argumental you idiot!-construction does not have. Also note in this context that in languages that otherwise allow or even force proper names to be preceded by an expletive definite article, the article must be absent when a proper name is used vocatively, which probably suggests that vocatives lack the DP-layer altogether; see e.g., Szabolcsi (1994) for a brief discussion of this for Hungarian. So, if the predication relationship cannot be

${ }^{41}$ A construction type that seems to provide support for an analysis in which the vocative phrase 'you idiot' is predicated of a subject is the exclamative construction in (9); it is repeated here as (i):
a. Eikel die je bent!
Jerk who you are
'You are such a jerk!'
b. Kreng dat je bent!
Bitch that you are!
'You are such a bitch!'

This exclamative construction consists of two parts (cf. De Rooij 1967): the first part is a bare (i.e., determiner-less) nominal constituent that can also be used as an independent vocative. The second part is an embedded clause, more particularly a relative clause with the specific property that besides the relative pronoun die 'who/which', we also find the element dat 'which'. The first part has all the properties of a vocative expression. It must be a determiner-less noun [cf. (iia)]; it can be modified by an intensifying adjective:

(ii) a.

*Een/de (stomme) eikel die je bent!
A/The (stupid) jerk that you are
'you are such a (stupid) jerk!'
*Een/*het kreng dat je bent!
A/The bitch that you are
'you are such a bitch!'

(iii) a. Stomme eikel die je bent! Stupid jerk who you are

b. Vuil kreng dat je bent! Dirty bitch that you are!

The crucial thing is that (stomme) eikel and (vuil) kreng in (i)/(iii) indirectly predicate, i.e., via the relative pronoun, over the subject $j e$ of the relative clause which represents a copular construction. In short, the vocative expression behaves like a predicate itself.

Notice now that it is also possible to say:
a. Jij (stomme) eikel die je bent! You (stupid) jerk who you are
b. Jij (vuil) kreng dat je bent! You (dirty) bitch that you are

One might want to interpret this as showing that jij (stomme) eikel and jij (vuil) kreng function (indirectly) as nominal predicates that predicate over the subject of the embedded copular clause.

${ }^{42}$ I'd like to thank an anonymous reviewer for emphasizing the relevance of this point and for making suggestions as to how this might be connected to the question about the external distribution (i.e., the 'root-level' status) of evaluative vocative expressions. 
established via D, what other alternatives remain? That is, what can idiot in you idiot! (and stommerik in doe se stommerik!) be predicated of?

Obviously, it can't be predicated of you, because you is itself contained in a PP which is in fact predicated of the property-denoting noun phrase headed by idiot/stommerik. A possibility one might explore is that vocatives are syntactically represented in terms of a null subject of which the vocative is predicated. Schematically and applied to the evaluative vocative expression doe se stommerik!: ${ }^{43}$

$$
\left[\mathrm{XP} \mathrm{YOU}_{\text {subject }}\left[\mathrm{FP}\left[\mathrm{PP}_{\mathrm{k}} \mathrm{t}_{\mathrm{doe}}\right]_{\mathrm{j}}\left[\mathrm{F}, \mathrm{F}(=-\mathrm{se})+\mathrm{X}_{\mathrm{i}}(=\varnothing)+\mathrm{P}_{\mathrm{k}}\left[\mathrm{XP} \text { stommerik }\left[\mathrm{x}^{\prime} \mathrm{t}_{\mathrm{i}} \mathrm{t}_{\mathrm{j}}\right]\right]\right]\right]\right]
$$

In this configuration, the nominal expression (doe se) stommerik is predicated of a silent second person pronoun. ${ }^{44}$ This pattern is reminiscent of the appositive patterns that we saw in (33) and (34), where the evaluative vocative expression was associated with a second person pronoun. Consider, for example, the Swedish example (33b) and the Dutch example (34b), which are repeated here as (58a) and (58b), respectively:

(58) a. [Du, din fuling, ] ska inte stjäla min grammatik.

You, your idiot, shall not steal my grammar.book

b. Ik geloof dat [jij, jij stomme idioot,] te hard werkt!

I believe that you, you stupid idiot, too hard work

Under the reasonable assumption that appositive phrases are licensed under predication (i.e., the appositive phrase predicates over the categorial host to which it is attached), one might propose that something similar is going on in representation (57). With respect to (57), where we have a silent second person pronoun, the question then obviously arises as to why the noun phrase consisting of the silent pronoun and the appositive phrase cannot occur in an argumental position (cf., e.g.,

\footnotetext{
${ }^{43}$ YOU should be interpreted as a silent (i.e., phonetically empty) second person pronoun.

44 The question, obviously, arises as to what the exact structural relationship is between the second person pronoun (YOU) and the appositive vocative expression, i.e., the FP doe se stommerik. Under an antisymmetry approach (Kayne 1994), right adjunction of the appositive phrase to the pronoun is excluded. A possible structure would be the one in (i), where $Y O U$ is the subject of a small clause configuration XP and doe se stommerik the predicative expression occupying the complement position of XP.
}

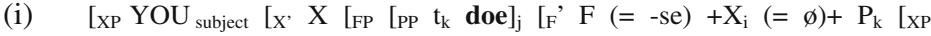
stommerik $\left.\left.\left.\left.\left.\left[\mathrm{x}, \mathrm{t}_{\mathrm{i}} \mathrm{t}_{\mathrm{j}}\right]\right]\right]\right]\right]\right]$ 
the ill-formed examples (32b) and (29b), which under the hypothesized presence of a silent YOU, receive the structures in (59a) and (59b), respectively. Recall that this was the (third) 'central' question that was raised at the end of Section 4.

a. $\quad *[Y O U$, din fuling, ] ska inte stjäla min grammatik.

b. *Ik geloof dat [YOU, jij stomme idioot,] te hard werkt.

If vocative expressions such as din fuling! and jij stomme idioot! have the abstract representation in (59), then the impossibility of having these surface forms in argumental positions may possibly be explained in terms of the distributional properties of empty pronominals (i.e., pro). More specifically, it may simply be due to the fact that in Germanic languages empty pronouns are not licensed in argumental positions, that is, there are no null subjects or null objects, to start with. ${ }^{45,46}$ It is only in special discourse or situational contexts that pronominal elements can sometimes be left out, e.g., in Dutch topic drop-constructions (e.g., Heb ik al gelezen! Have I already read; 'I have already read it/that book!'), where the

\footnotetext{
${ }^{45}$ I abstract away here from the (relevant) question as to which principle(s) govern(s) the distribution of empty pronominals in argumental position.

${ }^{46}$ Rather than relating the ill-formedness of (59) to the impossibility of having a silent noun (i.e., pro) in an argumental position, one might argue that the ungrammaticality is due to the fact that appositives cannot be combined with a phonetically empty (pronominal) host that has an (discourse/sentence) anaphoric function. In other words, it is the phonetic emptiness of the host that blocks the combination with an appositive evaluative vocative expression. Notice, for example, that in Dutch it is impossible to combine the vocative expression with PRO [cf. (ia)]. As shown by (ib), an overt pronoun may function as the host of an appositive expression.
}

(i) a. *Jij beloofde [om [PRO, jij idioot,] haar te helpen] You promised for PRO, you idiot, her to help

'You promised to help her, you idiot!'

b. Jij beloofde [dat [jij, jij idioot,]] haar zou helpen. You promised that you, you idiot, her would help

'You promised that you, you idiot, would help her.'

Another example which shows that empty pronominal elements typically do not function as hosts for appositive phrases comes from Brazilian Portuguese. As shown by (iia), it is possible to have an empty subject in argumental position, if the matrix and embedded subject are coreferential. Importantly, it is impossible to combine an appositive phrase with such an empty pronoun [cf. (iib)]:

(ii) a. Vocês $s_{i}$ disseram que $\mathrm{PRO}_{\mathrm{i}}$ pensam demais

you said that think too.much

'You said that you think too much.'

b. $\quad * V_{\text {ocês }}$ disseram que $_{\mathrm{i}}$ [PRO $\mathrm{PR}_{\mathrm{i}}$, seus idiotas, ] pensam demais

You said that you, youridiots, think too.much

'You think that you, you idiots, think too much.'

In (ii), I have represented the referential null subject as controlled PRO, despite being in the subject of a finite clause. The reason for representing the pronominal as PRO is that it must pick up the reference from the closest c-commanding antecedent. 
empty topic refers to an object (in casu a specific book) that is discourse familiar or situationally evoked. The emptiness of the second person pronoun in imperative clauses (e.g., Dutch Was jezelf! 'Wash yourself!') arguably also relates to the fact that the addressee is situationally accessible. Along the same lines, one might think that an evaluative vocative expression like din fuling/jij stomme idioot predicates over a second person pronominal, which may be phonetically empty because it is situationally accessible (i.e., it is the addressee). Although a detailed analysis of the 'pragmatic' licensing of the empty second person pronoun falls beyond the scope of this paper, it is interesting to observe that the two above-mentioned clausal environments featuring an empty pronominal have in common that they are 'root' constructions (in the sense of Emonds 1976). This property of being a root expression is something which is shared by the evaluative vocative expression, with the difference that the evaluative vocative is a nominal construction rather than a clausal one.

In sum, there are reasons for saying that the evaluative vocative expression (e.g., Aarschot Dutch doe se stommerik!, standard Dutch jij idioot!, Swedish din fuling!, English you idiot!) predicates over a second person pronominal, which refers to the addressee present in the situational context. Notice, finally, also that a Dutch example like (60) is also suggestive of the presence of a second person pronoun over which the evaluative vocative expression predicates: ${ }^{47}$
Ach [jij, jij idioot, $]_{\mathrm{k}} \mathrm{jij}_{\mathrm{k}}$ zou beter op moeten letten!
Oh you, you idiot, you should better PRT must pay.attention
'Oh you, you idiot, you should pay more attention!'

In this hanging topic-like construction, the sequence [jij, jij idioot] forms a left peripheral unit which is coreferential with the pronominal subject jij. Importantly, the vocative expression jij idioot functions as an apposition of an overt pronoun jij, which has a non-argumental status within the entire clause.

In what follows, I will abstract away from the presence of a silent/lexical second person pronoun over which the evaluative vocative expression predicates.

\section{5 'Inflected' se as 'se + spurious indefinite article'}

As shown in (55b), the small clause head that raises to $\mathrm{F}$ is phonetically empty in a pattern like doe se stommerik!. Interestingly, the small clause head sometimes seems to surface. Some further observations by Pauwels (1940, p. 204) about the formal manifestation of $s e(n)$ are relevant here. He points out that $s e(n)$ can be inflected. For

\footnotetext{
${ }^{47}$ Not unexpectedly, this is also possible in other languages, e.g., Brazilian Portuguese:

(i) [Vocês, [seus idiotas]], vocês pensam demais!

You, youridiots, you think too.much

'You, you idiots, you think too much!'
} 
example, $s e(n)$ can appear as sene and senen before a masculine singular noun. ${ }^{48}$ Arguably, the final $-n$ in senen is due to the phonetic rule that inserts $-n$ before a vowel.
a. O sene schelm Masc.sg.
(or: $o$ se schelm)
$O$ sene rascal
'Oh you rascal!'

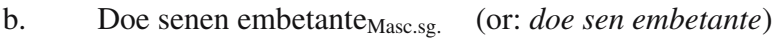
You senen teaser
'You teaser!'

Pauwels explores the idea that the inflected forms sene and senen are derived from the pattern $z o+$ the indefinite article een ('such a'), which surfaces in the forms zoene (i.e., zo-ene) and zoenen (i.e., zo + enen). In the end, however, he rejects that idea for reasons that I won't go into here. Although I agree with him that sene and senen should not be derived from zo + ene(n), I would like to keep one aspect of his analysis, viz. the idea that $n e(n)$ is an indefinite article.

That $n e$ is an indefinite article that shows up before masculine singular nouns is shown in (62). The appearance of the form nen is, just like with the form sen, due to phonetic factors. $^{49}$
a. ne vent
$a_{\text {masc.sg. } \text { man }}$
b. nen aap
$a_{\text {masc.sg. monkey }}$

If $n e$ in (62) is the indefinite article, sene(n) would be a composite form consisting of se (i.e., the nominal copula) and the indefinite article ne(n). The question obviously arises how this surprising combination of elements comes into existence. If we take the derived structure in $(55 \mathrm{~b})$ as our point of reference, the conclusion seems inescapable that the indefinite article is the small clause head X. By moving

\footnotetext{
${ }^{48}$ The reader should ignore the absence of the possessor in (61a). Arguably, there is an empty possessor present, which is contextually presupposed. I'll come back to that later.

49 The inflectional forms of the indefinite article are given in (ia):
}

(i)
a. $\quad$ pięt
$a_{\text {neut.sg. }}$ horse
b. on vrā
$a_{\text {fem.sg. }}$ woman
c. no røs
$a_{\text {masc.sg. }}$ giant 
ne from the small clause head position to $\mathrm{F}$, we get the sequence $\mathrm{F}+[\mathrm{x}$ ne], where $\mathrm{F}$ is spelled out as the nominal copula se. Schematically [for example (61b)]:

$$
\left[{ }_{F P}\left[{ }_{P P} t_{k} \text { doe }\right]_{j}\left[F^{\prime} F(=-s e)+n e(n)_{i}+P_{k}\left[x P \text { embetante }\left[x, t_{i} t_{j}\right]\right]\right]\right]
$$

The idea that an indefinite article fulfills the role of a DP-internal small clause head (i.e., an element that acts as a mediator between a subject and a predicate) was first proposed in Bennis et al. (1998). They identify a number of nominal constructions in which an indefinite article een ' $a$ ' appears which does not seem to belong to the nominal elements in its near environment. The relevant constructions are given in (64).

$\begin{array}{lll}\text { (64) } & \text { die idioot van een dokter } & \text { ( } N \text { van } N \text { construction) } \\ \text { that idiot of a doctor } & & \\ \text { b. } & \text { wat voor een jongen } & \text { (interrogative wat voor construction) } \\ & \text { what for a boy } & \\ & \text { 'what kind of boy' } & \\ \text { c. } & \begin{array}{l}\text { wat een idioot! } \\ \text { what an idiot }\end{array} & \\ & \text { 'such an idiot!' }\end{array}$

At first sight, there does not seem to be anything awkward about these constructions: een could be analyzed as a singular indefinite article that combines with the noun that follows (dokter/jongen/idioot). However, when we consider the examples in (65), it is quite obvious that the element een in these examples has a special grammatical behavior:

(65) die idioten van een jongens
those idiots of a boys
b. $\quad$ wat voor een jongens
what for a boys
'what kind of boys'
c. $\quad$ wat een idioten!
what a idiots
'such idiots!'

In these examples, the article een is followed by a plural noun. It is unlikely, then, that it is a regular indefinite article that combines with singular nouns. Notice also that een in (65) does not 'belong to' the preceding nominal element either: idioten in (65a) is a plural noun and wat in $(65 \mathrm{~b}, \mathrm{c})$ is a wh-element. Given this special syntactic behavior, Bennis et al. (1998) call this element a 'spurious' indefinite article.

Bennis, Corver, and Den Dikken further argue that the nominal constructions in (64) and (65) involve a DP-internal predication relationship, which is configura- 
tionally defined as a DP-internal small clause structure, i.e., XP [cf. the representations in (66)-(68)]. The small-clause-internal head $\mathrm{X}$ is taken to be the home of the spurious indefinite article. As such, the spurious indefinite article can be interpreted as an element that establishes a predication relationship between a DPinternal subject and predicate. It is further proposed that the constructions in (64) and (65) feature a DP-internal predicate displacement process that moves the predicate to a position preceding the small clause subject. (66) gives us the analysis of the $N$ of $N$-construction [see also (36)], (67) that of the wat voor-construction, and (68) that of the wat-exclamative construction. The a-examples represent the underlying small clause structures, which define the predication relationship; the b-examples represent the derived structures.

(66) a. $\quad[\mathrm{XP}$ dokter $[\mathrm{X},[\mathrm{x}$ een $][$ idioot $]]$

b. $\quad\left[\mathrm{DP} \operatorname{die}\left[\mathrm{FP}\right.\right.$ idioot $\left.\left.\left[\mathrm{F}, \mathrm{F}(=\mathrm{van})+\mathrm{X}_{\mathrm{i}}(=\mathrm{een})\left[\mathrm{XP} \operatorname{dokter}\left[\mathrm{x}, \mathrm{t}_{\mathrm{i}} \mathrm{t}_{\mathrm{j}}\right]\right]\right]\right]\right]$

(67) a. [xp jongens $\left[\mathrm{x}^{\prime}[\mathrm{x}\right.$ een $\left.\left.][\mathrm{wat}]\right]\right]$

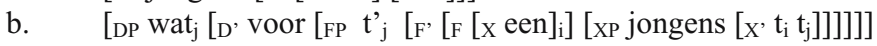

(68) a. $\quad[\mathrm{xP}$ idioten $[\mathrm{x},[\mathrm{x}$ een $][\mathrm{wat}]]]$

b. $\quad\left[D P w^{2} t_{j}\left[D,\left[D[+E X C L][x \text { een }]_{i}\right]\left[x p\right.\right.\right.$ idioot $\left.\left.\left.\left[x, t_{i} t_{j}\right]\right]\right]\right]$

In (66b), the operation of Predicate Inversion (i.e., predicate displacement of the A-movement type) has moved the nominal predicate idioot to [Spec,FP]. As indicated, the spurious indefinite article raises and adjoins to $\mathrm{F}$, creating the complex head ${ }_{\mathrm{F}} \mathrm{F}+$ $\mathrm{X}]$. F spells out as van, that is, the nominal copula (see Section 5.1) ${ }^{50}$ Thus, F $+\mathrm{X}$ surfaces as van + een. In (67b), the wh-predicate wat first undergoes Predicate Inversion to [Spec,FP] (in combination with movement of the spurious indefinite article een to F) and subsequently undergoes Predicate Fronting (i.e., predicate displacement of the A-bar movement type) to [Spec,DP]. ${ }^{51}$ In (68b), finally, the wh-predicate wat undergoes direct Predicate Fronting to [Spec,DP]. As indicated, the small clause head een raises to D, which is interpreted as a sort of 'Verb Second effect', that is, the head of a phrase must be 'lexicalized' if an operator-like element has moved into its Spec-position; see Bennis et al. (1998) for further details.

\subsection{Nominal constructions featuring the spurious indefinite article}

Against this background of nominal construction types featuring a spurious indefinite article, the appearance of such an element in possessive constructions

\footnotetext{
${ }^{50}$ Recall from Section 5.1 that X-to-F raising is required for reasons of locality, i.e., equidistance.

51 The question arises as to why the nominal copula cannot surface in wat voor-noun phrases like (67b); i.e., *wat voor van een jongens. Den Dikken (2006, p. 226) argues that the presence of an overt meaningless functional element, i.e., voor, under D causes the emptiness of $\mathrm{F}$ in a context in which it would otherwise be obligatorily overt. He refers to it as a "nonproliferation treaty", i.e., a desire to keep the amount of meaningless material to a minimum.
} 
like (61), which I take to involve predicate displacement as well, may be less surprising now. Interestingly and not unexpectedly, the inflectional forms of the indefinite article [i.e., $e, e n, n e(n)$ ] are also attested in other nominal environments that arguably involve predicate displacement. Consider the following examples from the dialect of Aarschot [examples based on Pauwels (1958)]. ${ }^{52}$
a. wåfø-ə pięt (wat voor-construction)
what + for $+a_{\text {neut.sg. }}$ horse
'what kind of horse'
b. wåfø-ən vrā
what + for $+a_{\text {fem.sg. }}$ woman
'what kind of woman'
c. wåfø-ne vęnt
what + for $+a_{\text {masc.sg. }}$ man
'what kind of man'
a. wåd-ə pięt
what $+a_{\text {neut.sg. }}$ horse
'what horse!
b. wåd-ənə vrā
$w h a t+a_{\text {fem.sg. }}$ woman
'what woman!'
c. wåd-ən vęnt
what $+a_{\text {masc.sg. man }}$
'what man!'
a. zu-a pięt
so $+a_{\text {neut.sg. }}$ horse
'such a horse'
b. zu-ən vrā
$s o+a_{\text {fem.sg. }}$ woman
'such a woman'
c. zu-ənə vęnt
so $+a_{\text {masc.sg. man }}$
'such a man'

As noted in Pauwels (1958, p. 350), the feminine singular form [i.e., the b-example in (69)-(71)] is also used when it is followed by a plural noun. This means that the indefinite article $\partial n$ is no longer felt to be singular in its interpretation. For example, in $z u$-ən buәmə (so + a trees; 'such trees'), - ən is no longer felt to be a singular indefinite article. To put it in the terms of Bennis et al. (1998), - $\partial n$ is an instance of the spurious indefinite article. I will assume that the derivation of the

${ }^{52}$ The attributive wh-word welak ('which') is inflected like an adjective (e.g., rruet 'big')

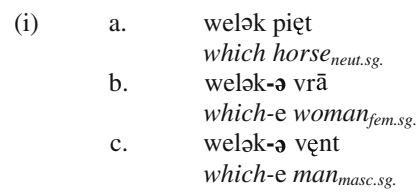
a. $\quad$ o rruet pięt
a big horse neut.sg.
b.' $\quad$ on $\gamma$ ruet-ə vrā
a big-ə woman $_{\text {fem.sg. }}$
c.' nə үruet-ə vęnt
abig-ə man $_{\text {masc.sg. }}$


noun phrase $z u$ - ən buәmə involves DP-internal Predicate Fronting of $z u$ (so; 'such') from the small clause predicate position to [Spec,DP], with concomitant head movement of the spurious indefinite article to D, quite along the lines of the exclamative noun phrase in (68). Schematically:

$$
\begin{array}{ll}
\text { a. } & {[\mathrm{XP} \text { buəmə }[\mathrm{x},[\mathrm{x} \text { ən] }[\mathrm{zu}]]]} \\
\mathrm{b} . & {\left[\mathrm{DP} \mathrm{Zu}_{\mathrm{j}}\left[\mathrm{D},\left[\mathrm{D}[\mathrm{x} \text { ən }]_{\mathrm{i}}\right]\left[\mathrm{xP} \text { buəmə }\left[\mathrm{x}, \mathrm{t}_{\mathrm{i}} \mathrm{t}_{\mathrm{j}}\right]\right]\right]\right]}
\end{array}
$$

\subsection{A note on ellipted evaluative vocative expressions}

After this discussion of the possible occurrence of the spurious indefinite article in patterns like (61), I would like to draw your attention to the existence of two doe sen $\mathrm{N}$-patterns in which one of the two nominals is phonetically unrealized. Consider, first, the pattern in (73): ${ }^{53}$

$$
\begin{array}{ll}
\text { a. } & \text { O sen dief! } \\
& \text { Oh se thief } \\
\text { 'You thief!' } \\
\text { b. } \quad \text { A se verken! } \\
\text { Ah se pig } \\
\text { 'You pig!' }
\end{array}
$$

Under the analysis as given in (55b), the complex head (in casu: $[\mathrm{F}+\mathrm{X}+\mathrm{P}]$, which surfaces as $-s e$ ) represents an 'independent' syntactic position which is syntactically separate from the preceding inverted predicate. This independent status is corroborated by the facts in (73), where the inverted predicate is phonetically empty (and pragmatically presupposed given the fact that the second person (i.e., the addressee) is contextually given). ${ }^{54}$

${ }^{53}$ Dutch vocative expressions of the type in (i) arguably also contain an empty second person pronoun. This is suggested by the fact that the vocative noun phrase can contain a second person reflexive pronoun, which must be associated with an antecedent:

$$
\begin{aligned}
& \text { Ach, } \text { pro }_{\mathrm{i}} \text { domme bewonderaar van jezelf } \mathrm{f}_{\mathrm{i}} \text { ! } \\
& \text { Oh, (you) stupid admirer of yourself } \\
& \text { Ach, } \mathrm{jij}_{\mathrm{i}} \text { domme bewonderaar van jezelf } \mathrm{f}_{\mathrm{i}}
\end{aligned}
$$

${ }^{54}$ An empty predicate is also found in other nominal contexts featuring predicate displacement. Take, for example, the following examples from Dutch:

(i) a. [Een boeken] heeft Jan gelezen

A books has Jan read

'Jan has read so many books!'

b. Jan heeft me toch [een boeken] gelezen!

Jan has me but a books read

'Jan has read so many books!'

In these examples, the noun phrase is an exclamative phrase. The fact that een is followed by a plural noun suggests that it is the spurious indefinite article. It is tempting to analyze these nominal constructions as in (ii), where $\varnothing$ stands for the empty (predicate) operator:

(ii) $\quad\left[D P \varnothing_{j}\left[D,\left[D[+E X C L][x \text { een }]_{i}\right]\left[x P\right.\right.\right.$ boeken $\left.\left.\left[x, t_{i} t_{j}\right]\right]\right]$

iㅡㄹ Springer 
I propose that these ellipted patterns have the following structure:

$$
\left.\left.\left[\mathrm{FP}\left[\mathrm{PP} \mathrm{t}_{\mathrm{k}} \text { pro }\right]_{\mathrm{j}}\left[\mathrm{F}^{\prime} \mathrm{F}(=-\mathrm{se})+\mathrm{X}_{\mathrm{i}}(=\varnothing)+\mathrm{P}_{\mathrm{k}}\left[\mathrm{XP} \text { verken }\left[\mathrm{x}, \mathrm{t}_{\mathrm{i}} \mathrm{t}_{\mathrm{j}}\right]\right]\right]\right]\right]\right]
$$

We also find the reverse pattern, that is, the inverted predicate (i.e., the possessor) is lexicalized, but the 'subject noun' is phonetically empty. ${ }^{55}$ The meaning of the (empty) nominal epithet remains unspecified, but the structural environment enforces a pejorative meaning. ${ }^{56}$
a. O doe se !
O you se
'Oh you!' (pejorative meaning)
b. $\quad\left[\mathrm{FP}\left[\mathrm{PP} \mathrm{t}_{\mathrm{k}} \text { doe }\right]_{\mathrm{j}}\left[\mathrm{F}^{\prime} \mathrm{F}(=-\mathrm{se})+\mathrm{X}_{\mathrm{i}}(=\varnothing)+\mathrm{P}_{\mathrm{k}}\left[\mathrm{XP}\right.\right.\right.$ pro $\left.\left.\left.\left[\mathrm{x}^{\prime} \mathrm{t}_{\mathrm{i}} \mathrm{t}_{\mathrm{j}}\right]\right]\right]\right]$

\subsection{Conclusion}

This concludes my discussion of the vocative pattern doe + se $(+$ spurious indefinite article $)+N$. I have analyzed se as an instance of the nominal copula that surfaces in contexts of DP-internal Predicate Inversion. In those cases in which $s e(n)$ remains bare (i.e., 'uninflected'), the small clause XP is headed by a phonetically empty head. For those cases in which it is 'inflected', I have analyzed this 'inflection' as an instance of the spurious indefinite article een, which functions as a small clause head $\mathrm{X}$ and appears attached to the functional head $\mathrm{F}$ after $\mathrm{X}$-to-F raising has applied.

\footnotetext{
55 As noted in Pauwels (1940), the pattern $O$ gij se! 'Oh you ${ }_{\mathrm{NOM}}$ se' is also found in the dialect of Aarschot.

${ }^{56}$ In Corver (2004), I argue that emptiness of the small clause subject is also found in the Dutch whexpression watte? (what-e; 'what?'), which typically appears as an independent expression (i.e., not as an argument of a verb). An example is given in (i):
}
(i)
A: Jan heeft iets leuks gekocht?
B: O ja? Watte?
A: Jan has something nice bought?
B: Oh yes? What-e?

The syntactic analysis of the expression watte is given in (ii), where (iia) represents the 'underlying' pattern (with $-e$ as an instance of the small clause head X) and (iib) is the derived structure which results from the application of Predicate Fronting:

(ii) $\quad$ a. $\quad$ Xxp pro (i.e., presupposed information) $[\mathrm{x},[\mathrm{x}-\mathrm{e}]$ wat $]]$

b. [wP wat $\left[\mathrm{w},-\mathrm{e}_{\mathrm{i}}\left[\mathrm{xP}\right.\right.$ pro $\left.\left.\left.\left[\mathrm{x}, \mathrm{t}_{\mathrm{i}} \mathrm{t}_{\mathrm{j}}\right]\right]\right]\right]$

As indicated in (iia), the empty subject (let's assume a 'pro') represents information that is pragmatically presupposed (i.e., familiar on the basis of information previously provided in the discourse). In (i), for example, there is the presupposed (i.e., background) information that 'there is something that John has bought'. In Corver (2004), it is argued that the same analysis applies to emphatic pronominal forms such as ikke (i.e., I + -e; 'I'). 


\section{The pattern 'second person pronoun + spurious indefinite article + epithet noun'}

Thus far, I have argued that an evaluative vocative expression like doe sen aap! (you + sen + monkey) involves DP-internal Predicate Inversion: a 'beheaded' prepositional predicate (i.e., [ $\left.{ }_{\mathrm{PP}} \mathrm{P}_{\varnothing}+d o e\right]$ ) is moved to [Spec,FP]. This predicate movement is made possible by concomitant head movement of $\mathrm{X}$ to $\mathrm{F}$, where $\mathrm{F}$ spells out as the nominal copula -se(n). As we saw in the previous section, $\mathrm{X}$ is sometimes lexicalized as the spurious indefinite article $n e(n)$, which yields forms such as $s e+n e(n)$ as realizations of the adjunction structure $[\mathrm{F} F+\mathrm{X}(+\mathrm{P})]$.

Interestingly, Pauwels (1940, p. 205) notes that in the regions Antwerp, Brabant, and Limburg the following patterns are also used: ${ }^{57}$

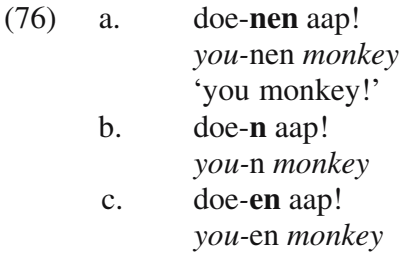

In these examples, the bound morpheme $-s e(n)$ is missing. The only bound morpheme that occurs in between the second person pronoun and the epithet noun is one of the variants $-n,-e n,-n e n$. Pauwels (1940, p. 205) interprets these bound morphemes as adjectival inflections that are attached to the pronominal 'stem' doe. Rather than interpreting them as an adjectival suffix, and in line with the approach taken in the previous section for the patterns in (61), I would like to propose that these bound morphemes are instances of the spurious indefinite article, i.e., the indefinite article that functions as the head X of a DP-internal small clause projection $\mathrm{XP}$. This most obviously applies to the form doenen in (76a), which may be decomposed into doe, -ne (the masculine singular form of the indefinite article), and $-n$ (the nasal sound that is inserted before a vowel). I will tentatively assume that the forms $n$ in (76b) and $-e n$ in (76c) are reduced instances of the spurious indefinite article.

If the spurious indefinite article typically occurs in nominal phrases featuring predicate movement [cf. (69)-(71)], then the patterns in (76) arguably involve predicate movement as well. There is one important difference, though, with the patterns doe se stommerik in (48a) and doe senen embetante in (61b): the nominal copula se is absent in (76). Recall that the presence of se was analyzed as a consequence of X-to-F movement in contexts of Predicate Inversion (i.e., predicate

\footnotetext{
${ }^{57}$ Pauwels (1940, p. 205) also notes the use of gij-n aap! (you ${ }_{\mathrm{NOM}}-n$ monkey; 'you monkey!') and gijnen aap! (you ${ }_{\mathrm{NO}}$-nen monkey; 'you monkey!') by certain speakers. 
displacement of the A-movement type). If we take the presence of the nominal copula $s e(n)$ as a diagnostic for the application of Predicate Inversion, we must conclude that Predicate Inversion has not applied in (76). There is an alternative analysis, though: Predicate Fronting (i.e., predicate movement of the A-bar movement type) has operated in (76). Schematically: ${ }^{58}$
a. $\quad\left[\mathrm{XP}\right.$ aap $\left[\mathrm{x},[\mathrm{x}\right.$ ne $]\left[\mathrm{PP} \mathrm{P}_{\varnothing}+\right.$ doe $\left.\left.]\right]\right]$
'base structure'
b. $\quad\left[D P\left[{ }_{p P} t_{k}+\text { doe }\right]_{j}\left[D^{\prime}\left[n e(n)+P_{k}(=\varnothing)\right]_{i}\left[x p\right.\right.\right.$ aap $\left.\left.\left.\left[\mathrm{x}^{\prime} \mathrm{t}_{\mathrm{i}} \mathrm{t}_{\mathrm{j}}\right]\right]\right]\right]$ derived structure

In (77a), the masculine singular indefinite article ne enters into a spec-head agreement relation with the masculine singular noun aap. The PP $P_{\varnothing}+$ doe ('to you') predicates over aap. The meaning of this expression roughly corresponds to: '(the property of being a) monkey is to you'. The pattern in (77b) is derived by moving the prepositional predicate to [Spec,DP]. As indicated, the spurious indefinite article that originates as a small clause head $\mathrm{X}$ undergoes head movement to $\mathrm{D}$, after the phonetically empty (dative) preposition $\mathrm{P}_{\varnothing}$ has incorporated into the small clause head ne. Notice that this Predicate Fronting analysis is quite similar to the one in (68b), where the exclamative wh-word wat (a predicate) is fronted to [Spec,DP] with concomitant movement of the spurious indefinite article to the head D. ${ }^{59}$

Our syntactic decomposition of doenen aap into doe (= pronoun) $+n e(n)$ (= spurious indefinite article) + noun arguably extends to the patterns in (21), repeated

\footnotetext{
${ }^{58} \mathrm{I}$ will assume that after incorporation of $\mathrm{P}$ into $\mathrm{X}, \mathrm{P}$ is no longer able to assign (dative) case to the second person pronoun. The pronoun that is dominated by a 'beheaded' PP (i.e., [PP $t_{k}+$ second person pronoun]) is spelled out as a nominative form, which I take to be a form corresponding to absence of case; see Section 6.

59 Another nominal construction type involving direct Predicate Fronting (i.e., predicate movement to [Spec, DP]) is exemplified in (i). These nominal constructions taken from the Dutch dialect of the Kempenland (cf. De Bont 1958, p. 386) are equivalents of English expressions such as how big a car, too big a car, that big a car, which have been analyzed in terms of DP-internal A-bar movement to [Spec,DP]; see e.g., Abney (1987), Corver (1990), Hendrick (1990). That forms such as schǒone, kǒoie, and lompe in (i) should not be analyzed as inflected adjectives is clear from the fact that attributive adjectives modifying an indefinite noun phrase do not carry an overt inflectional marker in the dialect of the Kempenland. This is shown, for example, by the attributive adjective wit ('white') in (ia), where there is no $-e$ attached to the adjective. The $-e$ following the adjectival phrases wa schǒon, te kǒoi, and zе̌u lomp corresponds to the neuter indefinite article (i.e., $e, \mathrm{a}_{\text {neut.sg. }}$ ) and is analyzed here as the spurious indefinite article. Under a Predicate Fronting analysis, a construction like zе̌u lompe vaerke in (ic) receives the analysis in (ii); see also Den Dikken (2006, p. 236) for a Predicate Fronting analysis of this type of construction:
}

\begin{tabular}{|c|c|}
\hline a. & $\begin{array}{l}\text { Wa schŏon-e wit vlěes! } \\
\text { What beautiful-e white meat } \\
\text { 'such a beautiful white meat' }\end{array}$ \\
\hline b. & $\begin{array}{l}\text { Et wa's te kŏoi-e weer. } \\
\text { It was too bad-e weather } \\
\text { 'The weather was too bad.' }\end{array}$ \\
\hline c. & $\begin{array}{l}\text { Hij is zĕu lomp-e vaerke. } \\
\text { He is so clumsy-e pig } \\
\text { 'He is such a clumsy pig.' }\end{array}$ \\
\hline $\begin{array}{l}\text { a. } \\
\text { b. }\end{array}$ & $\begin{array}{l}\text { [xP vaerke }[x,[x \text { e] zěu lomp }]] \\
{\left[{ }_{D P}[\text { zěu lomp }]_{j}\left[D,\left[[x \text { e }]_{i}+D\right]\left[x P \text { vaerke }\left[x, t_{i} t_{j}\right]\right]\right]\right]}\end{array}$ \\
\hline
\end{tabular}


here as (78), which do not feature doe but an object/oblique form of the pronoun, which is followed by a bound morpheme -en.
a. Jouw-en deugniet! (Western Brabantish; Kern 1927) your-en rascal 'You rascal!'
b. Jouw-en dikzak! your-en fatman 'You fatman!'

In Kern (1927, p. 156), the form jouwen in (78) is analyzed as a possessive adjective. Pauwels (1940, p. 203) makes the subtle reinterpretation that jouwen is a pronominal object-form (i.e., a personal pronoun) that is inflected as an adjective, that is, jouwen is jou $+-e n$. Building on and slightly reanalyzing Pauwels' structural analysis, I would like to propose that jou is a (dative) object form and that -en is an instance of the spurious indefinite article that heads the small clause XP, which consists of the subject deugniet and the dative PP $P+$ jou (i.e., 'the property of being a rascal is to you'). Schematically:
a. [XP deugniet $\left[\mathrm{X}^{\prime}[\mathrm{x}-\mathrm{en}]\left[\mathrm{PP} \mathrm{P}_{\phi}+\right.\right.$ jou $\left.\left.]\right]\right]$
'base structure'
b. $\quad\left[D P\left[P P P_{\phi}+\text { jou }\right]_{j}\left[D,(w)-e n_{i}\left[X P\right.\right.\right.$ deugniet $\left.\left.\left.\left[\mathrm{X}^{\prime} \mathrm{t}_{\mathrm{i}} \mathrm{t}_{\mathrm{j}}\right]\right]\right]\right]$
derived structure

As indicated in (79b), I assume that in these patterns the dative null preposition $\mathrm{P}$ has not been incorporated into the c-commanding head X. Since the (phonetically empty) dative assigning $\mathrm{P}$ is available within the inverted PP-predicate, dative case is assigned to the possessor noun phrase, whence the presence of the object form jou (rather than the subject form $j i j) .{ }^{60}$ I will assume that the sound $w$ is inserted as a result of a phonological process: more specifically, the glide $w$ is inserted after a stem ending in a vowel when the stem is followed by a bound morphemic element that begins with a schwa. ${ }^{61}$

\section{The pattern 'second person pronoun + epithet noun'}

Consider, finally, the 'bare' patterns in (80) and (81), 'bare' in the sense that no element intervenes between the second person pronoun and the epithet noun. The

\footnotetext{
${ }^{60}$ This may be interpreted along the lines of Emonds's (1985) principle of "alternative realization": the dative case morphology on jou serves as an alternative realization of the dative $\mathrm{P}$, as a result of which the $\mathrm{P}$ itself remains null and will not incorporate.

${ }^{61}$ This phenomeon is also found in standard Dutch with examples such as: barbecue[w]en 'to barbecue', echo[w] en 'to echo', judo[w]en 'to judo', kano[w]en 'to canoe', tango[w]en 'to tango'. See Trommelen and Zonneveld (1979) for discussion. 
second person pronoun has the nominative form in (80) and an accusative/oblique form in $(81):^{62}$
a. Doe aap!

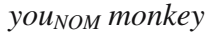
b. Gij NOM $_{\text {aap! }}$
You monkey
c. Jij
You monkey
(dialect of Aarschot)
(dialect of Aarschot)
(standard Dutch)
a. Jou duyvelskop! you $_{A C C / O B L}$ devil's.head
b. Jou vark!
you $_{A C C / O B L}$ pig
(17 ${ }^{\text {th }}$ century Dutch; Kern 1927)
(Afrikaans; Ponelis 1979, p. 127)

(81)

The pattern in (81) is quite similar to the pattern in (78). The only element that is missing at the surface is the spurious indefinite article. The DP-internal small clause $\mathrm{XP}$ is headed by a phonetically empty head X, here represented as [X $\varnothing]$. Under the assumption that this vocative pattern has a 'possessive meaning' [e.g., 'devil's head is to you' for (81a)] which can be read off the small clause structure in (82a), we can derive the surface order by Predicate Fronting of the dative PP to [Spec,DP], as in (82b). I will assume that the possessor receives a dative case from the (phonetically empty) preposition, which, importantly, has not been incorporated into the small clause head X.
a. [XP duyvelskop $\left[\mathrm{x},[\mathrm{x} \emptyset]\left[\mathrm{pP} \mathrm{P}_{\phi}+\right.\right.$ jou $]$
'base structure'
b. $\quad\left[D P\left[P P P_{\phi}+j o u\right]_{j}\left[D,[x \emptyset]_{i}\left[\mathrm{XP}\right.\right.\right.$ duyvelskop $\left.\left.\left[\mathrm{X}^{\prime} \mathrm{t}_{\mathrm{i}} \mathrm{t}_{\mathrm{j}}\right]\right]\right]$ derived structure

What about the evaluative vocative pattern in (80), featuring a nominative second person pronoun? An obvious way to go would be to say that this pattern represents the straight subject-predicate order: that is, an expression like jij aap has the meaning 'you are a monkey'. Thus, $j i j$ is the subject and aap is the predicate nominal. ${ }^{63}$

$$
\text { [DP D [xp jij [x'X aap]]] }
$$

\footnotetext{
${ }^{62}$ Van Ginneken (1954, p. 100) seems to suggest that both forms co-exist in the so-called "Waterlandse dialecten"” e.g., jij /jou stommeling! ( you $_{\mathrm{NOM}} / \mathrm{you}_{\mathrm{ACC}-\mathrm{OBL}}$ idiot).

${ }^{63}$ Potts and Roeper (2006) analyze the expression you fool! as a root-level small clause. In their analysis, the small clause is not part of a larger extended nominal projection. The fact that the evaluative vocative expression jij idioot! ('you idiot!') can function as the antecedent of a pronominal element is suggestive, though, for the nominal nature of the entire expression. Consider, for example, (i), where the second person pronoun jij is coreferential with jij idioot. Observe that small clause expressions like jij een idioot? ('you an idiot?') can only be referred to by the demonstrative dat 'that' in Dutch [cf. (ii)]. This contrast between the evaluative vocative expression jij idioot! and the small clause proposition jij een idioot? suggests that the constructions have a different categorial status.
}

(i) $\quad[\mathrm{Jij} \text { idioot }]_{\mathrm{k}}, \mathrm{jij}_{\mathrm{k}}$ zou beter op moeten letten!

You idiot, you should better PRT must pay.attention

'You idiot, you should pay more attention!'

(ii) $\quad$ Jij een idioot? $]_{\mathrm{k}}$, dat $\mathrm{k}_{\mathrm{k}}$ gelooft toch niemand.

You an idiot, that believes PRT nobody

'You (being) an idiot? Nobody will believe that.' 
As an alternative, one might argue that the derivation of the pattern jij aap also involves predicate displacement along the lines of jou duyvelskop in (82). The existence of patterns such as doe se stommerik! (48a), gij sen deugniet! (49a), and doenen aap! (76a), where the second person pronoun has a nominative form and where the presence of the nominal copula $[s e(n)]$ or the spurious indefinite article $[n e(n)]$ is diagnostic for the application of predicate displacement, shows that the displaced predicate can surface as a nominative second person pronoun. Recall that the appearance of the nominative form in those cases was related to the phenomenon of P-incorporation: after the phonetically empty (dative assigning) P is incorporated into a higher functional head, it is no longer able to assign dative case to its pronominal complement. Instead of the dative (i.e., object) form we get the nominative form in those cases. If it is further assumed that in the patterns in (80), just like in those in (81), the mediating small clause head is phonetically empty (i.e., $\varnothing)$, we get the derivation in (84) for the vocative expressions in (80):

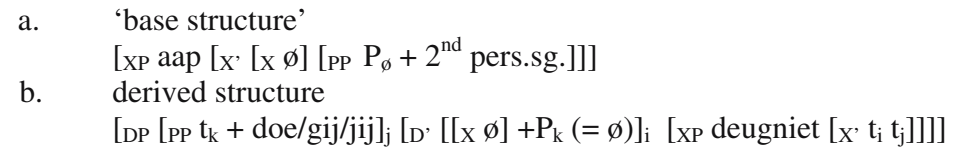

Admittedly, it is hard to find conclusive evidence on the basis of which a choice can be made for the pattern in (80) between a straight subject-predicate order analysis [cf. (83)] and a predicate displacement analysis [cf. (84)]. Taking the idea of cross-constructional symmetry seriously, one might also be tempted to analyze this vocative pattern in terms of predicate displacement.

\section{Jespersen's dit fae!}

In Sections 6, 7, and 8, I have argued for a predicate displacement analysis of what I have called evaluative vocative expressions, that is, expressions of the type 'second person pronoun + epithet noun'. I have argued that the various (inter- and intradialectal) surface manifestations of this pattern are due to an interplay of the following factors:

- The nature of predicate displacement, that is, Predicate Inversion (triggering the appearance of the nominal copula $[\mathrm{se}(n)]$ versus Predicate Fronting.

- The morphological realization of the small clause head X, that is, realization (1) as an (overt) spurious indefinite article or (2) as a null-element $\mathrm{X}_{\varnothing}$.

- The case form of the pronominal element, more particularly nominative (e.g., doe, gij, jij) versus dative (e.g., jou), where the appearance of the nominative form is associated with the phenomenon of P-incorporation and the appearance of the dative form is associated with the absence of P-incorporation.

Taking this as our theoretical background, let us consider again the Danish pattern dit fa!! (your cattle ${ }_{\mathrm{sg}}$; 'you fool!'), which was briefy discussed in Jespersen's The Philosophy of Grammar. Taking as our background the predicate displacement analysis of the internal syntax of evaluative vocative expressions, as proposed in the 
previous sections, I will explore a tentative analysis according to which the Danish pattern dit foe! [and its equivalents in other languages such as Norwegian (18), Swedish (19), and Frisian (20)] also involves predicate movement. ${ }^{64}$ More particularly, the second person pronoun starts out as a complement of the phonetically empty preposition $\mathrm{P}_{\varnothing}$. This prepositional phrase predicates over the epithet noun ( $f c e$ ) that occupies the specifier position of the DP-internal small clause XP. This is schematically represented in (85a). ${ }^{65}$ The inverted (i.e., pronoun + epithet noun) order is obtained by applying Predicate Fronting to the PP and by concomitant raising of the small clause head X to D.

$$
\begin{array}{ll}
\text { a. } & {\left[\mathrm{xP} f æ\left[\mathrm{x},[\mathrm{x}-\mathrm{t}] \mathrm{P}+\mathrm{Pron}_{2 \mathrm{p} . \mathrm{sg} .}\right]\right]} \\
\text { b. } & {\left[\mathrm{DP}\left[\mathrm{PP} \mathrm{P}_{\varnothing} \mathbf{d i}\right]_{\mathrm{j}}\left[\mathrm{F}, \mathrm{X}_{\mathrm{i}}(=-\mathbf{t})+\mathrm{D}\left[\mathrm{XP} \text { fæ }\left[\mathrm{x}, \mathrm{t}_{\mathrm{i}} \mathrm{t}_{\mathrm{j}}\right]\right]\right]\right.}
\end{array}
$$

As indicated in (85), I take the possessive form dit to be decomposable into the subparts $d i$, the pronominal part, and $-t$, which I consider to be an instance of the spurious indefinite article. ${ }^{66}$ The regular indefinite article in a language like Danish has two appearances: en for common gender (as in en mand 'a man') and et for neuter (as in et barn 'the child'). The final part of possessive pronominal forms such as din ('your', as in din hat 'your hat') and dit ('your', as in dit hus 'your house') has a clear resemblance to the (regular) indefinite article, that is, - $t$ and -en. On the basis of this resemblance, I tentatively propose that possessive pronouns such as dit and $d i n$ can be decomposed into $d i+t$ and $d i+e n$, respectively. I will assume that the indefinite article that appears attached to the pronominal element is an instance of the spurious indefinite article. ${ }^{67}$

This extension of the predicate movement approach towards Scandinavian possessive constructions raises a number of questions. First of all, (e)- $n$ and $-t$ do not occur in all possessive noun phrases featuring a pronominal possessor. The Danish noun phrase hendes bil (her-s car, 'her car'), for example, does not feature

\footnotetext{
${ }^{64}$ I would like to thank one of the reviewers for forcing me to have a more careful look at the Scandinavian evaluative vocative expressions by presenting me with potential problems for my analysis.

65 The spurious indefinite article $-t$ enters into a spec-head agreement relation with the epithet noun that occupies the specifier position of the small clause (XP). When the noun in [spec,XP] has common gender, we get the form din, as in din slyngel! (your rascal; 'you rascal!'). The derived representation of din slyngel! is given in (i):
}

(i) $\quad\left[{ }_{D P}\left[P P P_{\phi} \mathbf{d i}\right]_{j}\left[F^{\prime} X_{i}(=-e n)+D\left[X P\right.\right.\right.$ slyngel $\left.\left.\left[x, t_{i} t_{j}\right]\right]\right]$

${ }^{66}$ In traditional grammars, pronouns such as $\operatorname{din}$ (you common.sg $_{\text {) and }}$ dit (you neuter.sg $_{\text {) }}$ are considered to be inflected pronouns, where inflection regards gender and number. In the analysis proposed here, according to which din and dit can be decomposed into $d i-n$ and $d i-t$, respectively, $(e) n$ and $-t$ are considered to be instances of the spurious indefinite article.

${ }^{67}$ The spurious indefinite articles en and et are also found in other nominal constructions that have been argued to involve predicate displacement: e.g., hvad for en bog (what for a book; 'what kind of book'). 
the presence of $-(e) n$ or $-t .{ }^{68}$ If this pattern also involves predicate movement along the lines sketched above, then one has to assume that besides the overt spurious indefinite articles -en and $-t$, which head a DP-internal small clause XP, there are also silent (i.e., phonetically empty) instances of the spurious indefinite article. Thus, hendes bil would have the underlying structure in (86a) and the derived structure in (86b), where $-s$ is taken to be the nominal copula that surfaces in contexts of predicate inversion (i.e., predicate displacement of the A-movement type). ${ }^{69}$

$$
\begin{array}{ll}
\text { a. } & {\left[\mathrm{XP} \text { bil }\left[\mathrm{X},[\mathrm{x} \emptyset]\left[\mathrm{PP} \mathrm{P}_{\phi}+\text { hende }\right]\right]\right]} \\
\text { b. } & {\left[\mathrm{DP} \mathrm{D}\left[\mathrm{FP}\left[\mathrm{PP} \mathrm{P}_{\phi}+\text { hende }\right]_{\mathrm{j}}\left[\mathrm{F}, \mathrm{F}(=-s)+[\mathrm{x} \emptyset]_{\mathrm{i}}\left[\mathrm{XP} \text { bil }\left[\mathrm{X}, \mathrm{t}_{\mathrm{i}} \mathrm{t}_{\mathrm{j}}\right]\right]\right]\right]\right.} \\
& \text { derived structure }
\end{array}
$$

Although the presumed presence of an abstract (i.e., silent) spurious indefinite article in examples like (86) obviously is in need of more careful investigation, it suffices to observe that the existence of zero allomorphs of the spurious indefinite article has been argued for in Bennis et al. (1998, p. 109ff.), among others, in connection with the existence of the Dutch pattern wat voor jongen $(s)$ (what for boy(s); 'what kind of boy(s)') besides the pattern wat voor een jongen(s) (what for a boy(s); 'what kind of boy(s)'). The latter pattern features an overt instance of the spurious indefinite article. They argue, however, that the former pattern also features a spurious article X heading the DP-internal small clause XP, even though it does not surface phonetically. I will assume that something similar is going on with the possessive pattern hendes bil.

\begin{tabular}{|c|c|c|c|c|c|}
\hline & commo & gender & & neuter & gender \\
\hline a. & $\min$ & my & a.' & $\operatorname{mi} t$ & my \\
\hline b. & $\operatorname{din}$ & your & b.' & $\mathrm{di} t$ & your \\
\hline c. & $\sin$ & his/her & c.' & $\mathrm{sit}$ & his/her \\
\hline d. & hans & his & d.' & hans & his \\
\hline e. & hendes & her & e.' & hendes & her \\
\hline f. & dens & its & f.' & dens & its \\
\hline g. & dets & its & g.' & dets & its \\
\hline h. & vores & our & h.' & vores & our \\
\hline i. & jeres & your & i.' & jeres & your \\
\hline j. & deres & their & j.' & deres & their \\
\hline
\end{tabular}

${ }^{68}$ The complete paradigm for Danish possessive pronouns is given in (i):

(i)

The forms $\mathrm{min} / \mathrm{mit}$, din/dit and the reflexive possessive pronominal sin/sit clearly share their final part with the common and neuter indefinite article en/et. Besides the pattern vores 'our', Danish also has the forms vor ('our'; common gender) and vort ('our'; neuter gender). In the latter example, we distinguish the element $-t$ again. The forms vor and vort are more formal or solemn than vores, which is used in modern colloquial Danish.

${ }^{69}$ Observe that (85b) differs from (86b) as regards the nature of the DP-internal predicate movement operation. (85b) features predicate fronting (i.e., A-bar type predicate movement) and (86b) predicate inversion (i.e., A-type predicate movement). I take the presence of the nominal copula $-s$ to be a diagnostic for the application of predicate inversion. 
Another question that the predicate displacement analysis of Scandinavian possessives might raise comes from the existence of possessive pronouns that are postnominal. Take, for example, the following noun phrase from Norwegian:

$$
\begin{array}{lll}
\text { den } & \text { nye } & \text { bil-en min } \\
\text { def.masc.sg } & \text { new.def } & \text { car-defmy.masc.sg } \\
\text { 'my new car' } & &
\end{array}
$$

If the $-n$ at the end of $\min$ is an instance of a spurious indefinite article and if the formation of the surface form $\min$ results from the application of predicate movement, then, somehow, predicate movement must have applied in this construction, even though the pronoun min seems to occupy a position low down in the noun phrase.

One way of approaching this issue is by drawing a parallel with the syntax of French possessive noun phrases such as une voiture de Jean (a car of John; 'a car of John's'). According to Den Dikken (2006, p. 238), the derivation of this possessive construction involves the movement steps in (88). In (88b), predicate inversion has applied to the dative PP predicate, triggering the appearance of the nominal copula de. After remnant movement of the small clause XP around the inverted PP predicate and head movement of the complex head $\left.{ }_{\mathrm{F}} \mathrm{F}(=d e)+\mathrm{X}\right]$ to $\mathrm{D}$ have taken place, we get the linear order une voiture de Jean. ${ }^{70}$ The possessor Jean occupies a position at the (surface) end of the noun phrase, even though it has undergone a DP-internal predicate displacement operation. Its final position is simply due to the fact that the small clause XP containing the trace of the displaced possessor has also undergone DP-internal movement.

$$
\begin{aligned}
& \text { a. } \quad\left[\mathrm { xP } \text { POSSESSUM (= une voiture) } \left[\mathrm{x}, \mathrm{X}\left[{ }_{\mathrm{PP}} \mathrm{P}_{\mathrm{dative}} \text { POSSESSOR }(=\grave{a}\right.\right.\right. \\
& \text { Jean)]]] } \\
& \text { b. } \quad\left[\mathrm{FP}\left[P P P_{\text {dative }} \text { Jean }\right]_{\mathrm{i}}\left[\mathrm{F}, \mathrm{F}(=d e)+\mathrm{X}_{\mathrm{j}}\left[\mathrm{XP} \text { une voiture }\left[\mathrm{x}, \mathrm{t}_{\mathrm{j}} \mathrm{t}_{\mathrm{i}}\right]\right]\right]\right] \\
& \text { c. } \quad\left[\mathrm { DP } [ \mathrm { XP } \text { une voiture } [ \mathrm { X } , t _ { j } t _ { i } ] ] _ { \mathrm { k } } \left[\mathrm{D}, \mathrm{D}+[\mathrm{F} F(=d e)+\mathrm{X}]_{1}\left[{ } _ { \mathrm { FP } } [ { } _ { \mathrm { PP } } \mathrm { P } _ { \text { dative } } \mathrm { Jean } ] _ { \mathrm { i } } \left[\mathrm{~F}, \mathrm{t}_{1}\right.\right.\right.\right. \\
& \left.\left.\left.\left.\left[\mathrm{XP} \mathrm{t}_{\mathrm{k}}\right]\right]\right]\right]\right]
\end{aligned}
$$

One might propose now that the Norwegian pattern in (87) is derived along the following lines:
a. $\quad\left[\mathrm{xP}\right.$ POSSESSUM (= nye bil) $\left[\mathrm{x}, \mathrm{X}(=-\mathrm{n})\left[\mathrm{pP} \mathrm{P}_{\text {dative }}\right.\right.$ POSSESSOR $(=\mathrm{mi})]]]$
b. $\quad\left[\mathrm{FP}\left[P P P_{\text {dative }} m i\right]_{\mathrm{i}}\left[\mathrm{F}, \mathrm{F}+-n_{\mathrm{j}}\left[\mathrm{XP}\right.\right.\right.$ nye bil $\left.\left.\left.\left[\mathrm{X}, \mathrm{t}_{\mathrm{j}} \mathrm{t}_{\mathrm{i}}\right]\right]\right]\right]$
c. $\quad\left[\mathrm{wP}\left[\mathrm{XP} \text { nye bil }\left[\mathrm{X}, t_{j} t_{i}\right]\right]_{\mathrm{k}}\left[\mathrm{w},\left[\mathrm{w}\right.\right.\right.$ en] $\left.\left[\mathrm{FP}\left[\mathrm{PP} \mathrm{P}_{\mathrm{dative}} \mathrm{mi}\right]_{\mathrm{i}}\left[\mathrm{F}, \mathrm{F}+n_{\mathrm{j}}\left[\mathrm{XP} \mathrm{t}_{\mathrm{k}}\right]\right]\right]\right]$
d. $\quad\left[\mathrm{DP}\left[\mathrm{D}\right.\right.$ den] $\left[\mathrm{wP}\left[\mathrm{XP} \text { nye bil }\left[{ }_{X}, t_{j} t_{i}\right]\right]_{\mathrm{k}}\left[\mathrm{w},\left[\mathrm{w}\right.\right.\right.$ en] [FP $\left[\mathrm{PP} \mathrm{P}_{\text {dative }} \mathrm{mi}\right]_{\mathrm{i}}\left[\mathrm{F}, \mathrm{F}+n_{\mathrm{j}}[\mathrm{XP}\right.$ $\left.\left.\left.\left.\left.\left.\mathrm{t}_{\mathrm{k}}\right]\right]\right]\right]\right]\right]$

\footnotetext{
${ }^{70}$ See also Kayne's (1994) analysis of two pictures of John's, where two pictures is taken to be a phrase that is moved to [Spec,DP] and as a result of that precedes the sequence of John's. In Kayne's analysis, as opposed to Den Dikken's, of is analyzed as a (prepositional) D and not as a nominal copula that surfaces in contexts of A-type predicate movement. Kayne's structure for two pictures of John is given in (i).
} 
(89a) represents the underlying order, with $m i$ being a pronominal complement of P. In (89b), predicate inversion has applied to the PP $P+m i$. In (89c), the small clause XP has undergone DP-internal movement to the Spec-position of the phrase WP, which I take to be headed by the enclitic post-nominal determiner. ${ }^{71}$ In (89d), finally, the definite determiner is merged with WP and forms a DP.

Interestingly, the postnominal possessive pattern is not possible with evaluative possessive constructions:
den (forbanna) idiot-en din
(Norwegian)
the damned idiot-def your
'your (damned) idiot' / '*you damned idiot!'

So, you must have the pronominal possessive pattern:
Din (forbanna) idiot!
(Norwegian)
Your damned idiot
'You damned idiot!'

The impossibility of (90) as an evaluative vocative expression might be related to the observation (cf., e.g., Szabolcsi 1994) that vocative noun phrases are typically of a nominal projection type other than DP (i.e., the DP-level is associated with argumenthood). ${ }^{72}$

Another observation one might make, when a comparison is made between the 'regular' possessive noun phrase and the evaluative vocative expression, is the fact that for most speakers (of Norwegian), pronominal possessors can appear in prenominal position only if they are focused. ${ }^{73}$ Thus:

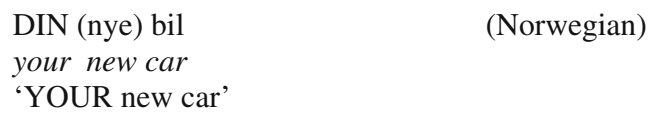

(Norwegian)

It is not so obvious that the obligatory prenominal occurrence of the possessive pronoun in vocative expressions like (91) is associated with focus. The pronominal element does not seem to enter any new information into the discourse or stand in a contrastive relationship with another possessor. Remember, though, from the Dutch example (15) that in a language like Dutch the second person pronoun in evaluative vocatives must be a strong form, as in jij idioot! ('you idiot!'). The weak possessive pronominal form je is not permitted in the evaluative vocative expression: *je idioot!

\footnotetext{
${ }^{71}$ The exact nature of the head W, obviously, is in need of further investigation. With Kayne (2000), I will simply use W as a mnemonic for 'word order': movement of the small clause XP to [Spec,WP] yields the word order in which the possessum precedes the (inverted) possessor. In line with previous analyses, one might analyze it as a 'lower' determiner-position (referred to by ART in Delsing 1988). For discussion of the semantic contribution of this enclitic article, see also Kester (1996, p. $146 \mathrm{ff}$.), who associates -en with the notion of 'familiarity' (i.e., the entity that the noun refers to is discourse accessible or situationally evoked).

72 As noted in Delsing (1988, p. 38) and Kester (1996, p. 146), the enclitic article -en may appear in Swedish vocative nominal expressions such as those in (i):
}

(i) Godmorgen, doktorn (Swedish; Delsing 1988, p. 39) Good.morning, doctor.the 'Good morning, doctor!'

73 This was pointed out to me by one of the reviewers.

iㅡㄹ Springer 
('you idiot!'). One might argue that this strong pronominal form relates to the deictic usage of the second person; it refers to the addressee present in the situational context. Pronominals with a deictic function typically have a (phonologically) strong form (e.g., jij, as opposed to je, in a language like Dutch). This is exemplified in (93):

$$
\begin{aligned}
& \text { Hé } \mathrm{jij} / * \mathrm{je}, \quad \text { ga weg! } \\
& \text { Hey you } \text { strong }_{\text {/you }} \text { weak, go away } \\
& \text { 'Hey you, go away!' }
\end{aligned}
$$

In short, even though a predicate displacement analysis of the Danish (possessive) evaluative expression dit fae! may need some further investigation, I hope it is clear from the above discussion that such an analysis should not be rejected immediately either. Taking a perspective of cross-linguistic uniformity on the syntax of this construction type, I analyze the possessor as a displaced predicate (more particularly, a displaced dative PP) and analyze $-n /-t$, which superficially appear attached to the pronominal, as instances of the spurious indefinite article. ${ }^{74}$

\footnotetext{
${ }^{74}$ A reviewer observes the interesting possessive construction in (i), which is attested in certain varieties of Norwegian, and points out that it seems quite hard to account for all the agreeing endings (i.e., $-n$ of $\mathrm{min} / \mathrm{din}$ ) as spurious articles:
}

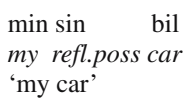

The pattern in (i) is an instance of the doubling possessive pattern, which is familiar from Norwegian noun phrases such as Kari sin bil (Kari refl.poss. car; 'Kari's car'). The question raised by the pattern in (i) is how the $-n$ on $\min$ can ever be interpreted as a spurious indefinite article, which typically appears in contexts of predicate movement. Given the non-agreement of $\min$ and $\sin$ (i.e., 1.sg. versus 3.sg.) in (i), it is not very likely that $\sin$ 'doubles' the possessor $\min$. As a matter of fact, if $\sin$ requires the presence of a third person (doubling) possessor, we must assume that such a third person doubling possessor is also present in (i). I will follow here a suggestion by Corver (2007) for the analysis of the occurrence of 'genitival' proper names (e.g., Jantjes; Johnny's; 'Johnny') in argumental positions in the clause of certain Dutch dialects (e.g., literally translated in English: “I saw John's”; meaning: 'I saw John'). In this paper, I argue that these 'argumental' 'genitival' proper names are actually hidden possessive constructions, whose possessum consists of a silent (i.e., phonetically) grammatical noun PERSON. Thus, Jantje-s is actually: Jantje-s PERSON. When we extend this analysis to min in (i), min stands for min PERSON. The possessive noun phrase min PERSON is a third person phrase, whence the agreement with $\sin$ in (i); i.e., $[\mathrm{min} \mathrm{PERSON}]_{j} \sin _{j}$ bil. When we analyze the formation of the possessive pronominals in (i) in terms of predicate displacement and movement of the spurious indefinite article, we may associate the following derivation with the pattern in (i).

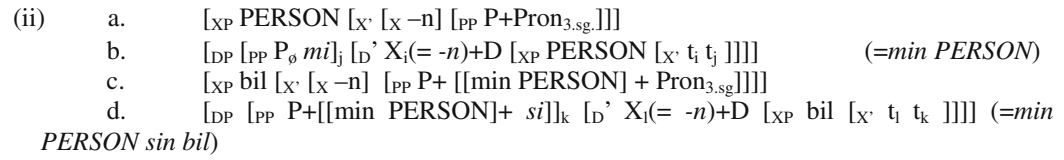

(iia) represents the 'underlying structure' of $\min P E R S O N$, i.e., 'PERSON [to me]'. (iib) is the derived structure after application of predicate fronting of the PP 'to me' and head movement (i.e., adjunction) of the spurious indefinite article $-n$ to D. (iic) is the structure that corresponds to 'car [to my PERSON]'. Representation (iid) results from the application of predicate fronting to the PP 'to [[my PERSON] pron ${ }_{3 . s g}$.', where my PERSON occupies the spec-position of the third person pronoun [say: spec,DP] with concomitant head movement of the spurious article $-n$ to $\mathrm{D}$. 
To add force to the idea that possessive pronominals consist of a (personal) pronoun plus a phonologically attached spurious indefinite article, I would like to draw your attention to some facts from the Dutch dialect of Aarschot, which was discussed in Section 6. Interestingly, in this dialect, we also find that the 'inflectional' part of the possessive pronoun corresponds in form to the indefinite article. Consider, for example, the following first and third person singular weak possessive forms (examples taken from Pauwels 1958):

(94) 1st person singular

$$
\begin{array}{ll}
\text { a. } & \text { m-ə } \\
& m \text { - } a_{\text {fem.sg. }} \\
& \text { 'my' } \\
\text { b. } & \text { m-ən } \\
& \text { m- } a_{\text {neut.sg. }} \\
& \text { 'my' } \\
\text { c. } \quad \text { m-ənə(n) } \\
\\
\text { m- } a_{\text {masc.sg. }} \\
\text { 'my' }
\end{array}
$$

$$
\begin{aligned}
& \text { 3rd person singular (dialect of Aarschot) } \\
& \text { a.' z-o } \\
& z \text {-a } a_{\text {fem.s. }} \\
& \text { 'his' } \\
& \text { b.' z- on } \\
& z-a_{\text {neut.sg. }} \\
& \text { 'his' } \\
& \text { c.' z-ənə(n) } \\
& z-a_{\text {masc.sg. }} \text {. } \\
& \text { 'his' }
\end{aligned}
$$

If this decomposition of possessive pronominal forms is adopted, a possessive noun

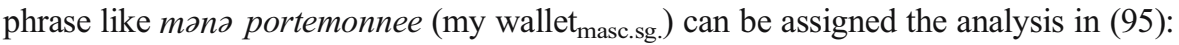

(95) a. $\quad\left[\mathrm{xP}\right.$ portemonnee $\left.\left[\mathrm{x},[\mathrm{x}-\partial n \partial]\left[\mathrm{PP} \mathrm{P}_{\phi} \mathrm{PRON}_{1 \mathrm{p} . \mathrm{sg} .}(=m-)\right]\right]\right]$

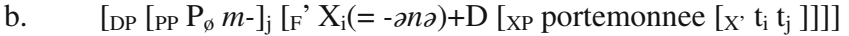

To summarize, I have argued that the Danish pattern dit foe! can be assigned the same analysis as the one I proposed in Section 7 for vocative expressions such as doe-nen aap! in the dialect of Aarschot. Jespersen's intuition that at an abstract (i.e., nonconstruction-specific) level dit foe! relates to the nominal constructions in (1) and (2) is captured configurationally: all these structures derive from a subject-predicate base order and the surface order results from the application of DP-internal predicate displacement.

\section{Uniformity and diversity}

Let me briefly return to the three patterns that can roughly be distinguished and that are illustrated in (96) on the basis of variants that are attested in Flemish Dutch:

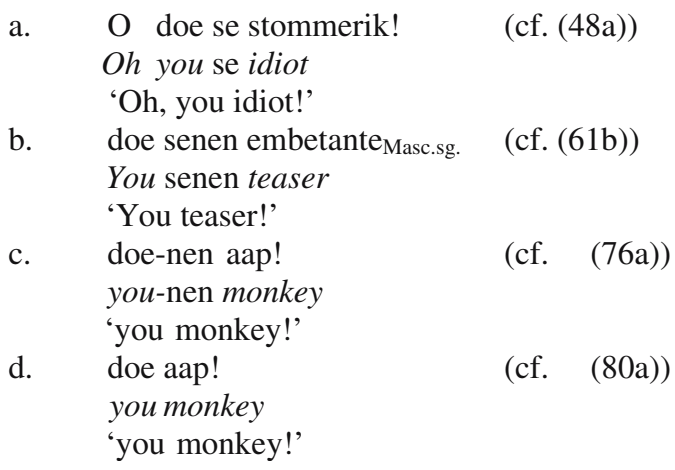


Thus far, I have analyzed the patterns in (96a) and (96b) in terms of Predicate Inversion (i.e., predicate displacement of the A-movement type), that is, movement of the 'beheaded' PP that contains the pronoun to [Spec,FP]. The patterns $(96 \mathrm{c}-\mathrm{d})$ were analyzed in terms of (direct) Predicate Fronting to [Spec,DP], that is, movement of the 'beheaded' PP containing the pronoun to the left edge position of the noun phrase. The parallelism between (96a-b), on the one hand, and (96c-d), on the other, can be 'strengthened' if we assume that in the former patterns also the pronoun ultimately moves to [Spec,DP]. That is, after application of DP-internal Predicate Inversion, the (prepositional) predicate containing the pronoun moves on to $[$ Spec,DP], with concomitant head movement of the complex head $[\mathrm{F}+\mathrm{X}+\mathrm{P}]$ to D. Schematically:
a. $\quad\left[{ }_{D P}\left[{ }_{P P} t_{k} d o e\right]_{j}\left[D^{\prime},\left[F(=-s e)+X_{i}(=\varnothing)+P\right]_{k}+D\left[F_{F P} t^{\prime}{ }_{j}\left[F^{\prime}, t^{\prime}{ }_{k}[\mathrm{XP}\right.\right.\right.\right.$ stommerik $\left.\left.\left.\left.\left[\mathrm{x}, \mathrm{t}_{\mathrm{i}} \mathrm{t}_{\mathrm{j}}\right]\right]\right]\right]\right]$
b. $\quad\left[\mathrm{DP}\left[\mathrm{PP}_{\mathrm{k}} \mathrm{t}_{\mathrm{k}}\right.\right.$ doe $_{\mathrm{j}}\left[\mathrm{D}^{\prime},\left[\mathrm{F}(=-\mathrm{se})+\mathrm{X}_{\mathrm{i}}(=-\mathrm{nen})+\mathrm{P}\right]_{\mathrm{k}}+\mathrm{D}\left[\mathrm{FP}^{\mathrm{t}} \mathrm{t}_{\mathrm{j}}\left[\mathrm{F}^{\prime} \mathrm{t}^{\prime}{ }_{\mathrm{k}}[\mathrm{XP}\right.\right.\right.$ embetante $\left.\left.\left.\left.\left[\mathrm{x}, \mathrm{t}_{\mathrm{i}} \mathrm{t}_{\mathrm{j}}\right]\right]\right]\right]\right]$

This uniform approach according to which the PP-predicate containing the second person pronoun moves to [Spec,DP] (directly or indirectly) might be related to the 'topical' status of the second person pronoun. The fronted pronoun refers to a contextually given individual (i.e., the addressee). Its topical status is also in line with the possibility of 'dropping' the second person pronoun, as in (73). A parallel might be drawn between this DP-internal topic drop and the clause-internal topic drop that is familiar from examples like (98), where a third person subject pronoun has been 'dropped': 75

(98) [Person A looking at a person who is silent all the time]

Heeft zeker zijn tong ingeslikt

Has surely his tongue swallowed

'He has surely lost his tongue.'

In summary, I have discussed different manifestations of the evaluative vocative expression 'second person pronoun + epithet noun'. The various (inter- and intradialectal) surface patterns have been argued to be due to an interplay of the following factors: (1) the nature of predicate displacement (e.g., direct Predicate Fronting or Predicate Inversion in combination with Predicate Fronting); (2) the morphological realization of the small clause head $X$, that is, realization (a) as an (overt) spurious indefinite article or (b) as a null-element $\mathrm{X}_{\varnothing}$; (3) the case form of the

\footnotetext{
${ }^{75}$ In example (75), the epithet noun is 'ellipted' (i.e., the evaluative part remains unexpressed) and the second person pronoun is present. The pronoun is pronounced emphatically and might be treated as a contrastive topic, where 'you' is implicitly contrasted with individuals other than 'you'.
} 
pronominal element (nominative versus dative), which was related to the phenomenon of P-incorporation.

What is interesting is that similar dimensions of (morpho)syntactic diversity are attested in other nominal constructions. From the perspective of cross-constructional parallelism, this 'sameness in diversity' (i.e., dimensions of variation attested in construction type A are arguably also attested in construction type B) may not be unexpected. Although a complete discussion of this cross-constructional parallelism in diversity is beyond the scope of this paper, I would like to close off this section by briefly mentioning some variants of the wat voor-construction, which in a certain way are similar to the variants of the evaluative vocative expression that I have discussed in this article.

(99) a. [Wåføən töfl] zodə wilə?(dialect of Aarschot, Pauwels 1958, p. 351) What.for.a table would.you want

'What kind of table would you like to have?'

b. [DP wå $\left[\mathrm{D}, \mathrm{f} \varnothing\left[\mathrm{FP} \mathrm{t}_{\mathrm{j}}{ }_{\mathrm{j}}\left[\mathrm{F},\left[\mathrm{F}[\mathrm{x} \text { ən }]_{\mathrm{i}}\right]\left[\mathrm{XP}\right.\right.\right.\right.$ töfl $\left.\left.\left.\left.\left[\mathrm{x}, \mathrm{t}_{\mathrm{i}} \mathrm{t}_{\mathrm{j}}\right]\right]\right]\right]\right]$

(100) a. [Wådən töfl] zodə wilə? (dialect of Aarschot, Pauwels 1958, p. 351)

What.a table would.you want

'What kind of table would you like to have?'

b. [DP wåt $\mathrm{j}_{\mathrm{j}}\left[\mathrm{D},\left[\mathrm{D}[\mathrm{x} \text { ən }]_{\mathrm{i}}\right]\left[\mathrm{xP}\right.\right.$ töfl $\left.\left.\left.\left[\mathrm{x}, \mathrm{t}_{\mathrm{i}} \mathrm{t}_{\mathrm{j}}\right]\right]\right]\right]$

(101) a. [Wå töfl] zodə wilə? (dialect of Aarschot, Pauwels 1958, p. 351)

What.a table would.you want

'What kind of table would you like to have?'

b. [DP wåj $\left[D^{\prime}\left[\mathrm{D}[\mathrm{x} \emptyset]_{\mathrm{i}}\right]\left[\mathrm{xP}\right.\right.$ töfl $\left.\left.\left.\left[\mathrm{x}, \mathrm{t}_{\mathrm{i}} \mathrm{t}_{\mathrm{j}}\right]\right]\right]\right]$

(102) a. [Watse tang] moet ek gebruik?'n Groterige een.

(Afrikaans; Ponelis 1979)

What-se pincers must I use? A bigger one

'What kind of pincers should I use? A bigger pair of pincers.'

b. [DP [DP Wat $]_{j}\left[\mathrm{D},\left[\mathrm{F}(=-\mathrm{se})+\mathrm{X}_{\mathrm{i}}(=\varnothing)\right]_{\mathrm{k}}+\mathrm{D}\left[\mathrm{FP} \mathrm{t}_{\mathrm{j}}{ }_{\mathrm{j}}\left[\mathrm{F}, \mathrm{t}^{\prime}{ }_{\mathrm{k}}\left[\mathrm{XP} \operatorname{tang}\left[\mathrm{x}, \mathrm{t}_{\mathrm{i}} \mathrm{t}_{\mathrm{j}}\right]\right]\right]\right]\right]$

The first three patterns are all from the dialect of Aarschot (see Pauwels 1958, pp. 350-51). The pattern in (99) involves the operations of Predicate Inversion and subsequent Predicate Fronting and features an overt instance of the spurious indefinite article. At an abstract level, it is similar to the derivation of doe senen embetante! in (97b). The pattern in (100) involves direct Predicate Fronting to [Spec, $\mathrm{DP}$ ] and movement of an overt spurious article to D. This parallels the derivation of doe-nen aap! in (77b). The pattern in (101) is derived by direct Predicate Fronting of the wh-predicate to [Spec,DP] with concomitant movement of a phonetically empty small clause head $\mathrm{X}$ to $\mathrm{D}$. This derivation is similar to the pattern doe deugniet! in (84b). The pattern in (102), which is from Afrikaans, is interesting because it features the morpheme se after the wh-word wat. ${ }^{76}$ I will tentatively assume that this

\footnotetext{
${ }^{76}$ The element se is also attested in possessive noun phrases in Afrikaans, as in: Jan se geld (John se money; 'John's money'), die boek se omslag (that book se cover; 'that book's cover'). See Ponelis (1979, pp. 126-28).

钐 Springer
} 
se is the bound morphemic nominal copula that we also found in doe se stommerik! in (55b); see also (97a) for a reanalysis of the construction in terms of Predicate Inversion and subsequent Predicate Fronting. If we assume that se surfaces as a result of the application of Predicate Inversion and if we further assume that the wh-word wat must end up in the Spec-position of a [+WH] D-head (cf. Bennis et al. 1998), we can represent the derivation of this pattern as in (102b). Predicate Fronting moves the wh-word wat from [Spec,FP] to [Spec,DP] and, as indicated, the complex head $[\mathrm{F}(=\mathrm{se})+\mathrm{X}(=\varnothing)]$ raises and adjoins to $\mathrm{D}$.

\section{Conclusion}

In this article, I have investigated certain aspects of the internal syntax of evaluative vocative expressions. This construction superficially consists of a second person pronoun and an epithet noun. Different manifestations of this construction type were discussed. The major dimensions of (morpho)syntactic diversity were related to the following properties: (1) the nature of the predicate displacement operation involved; (2) the overtness versus covertness of the small clause head X; (3) the case form of the second person pronoun. A shared property of all patterns is that they all 'start from' a predication structure, in which the epithet noun is the subject and the second person pronoun is part of a predicative PP (i.e., 'to you'). The surface order is derived by predicate displacement of the prepositional predicate to a position preceding the epithet noun. According to the structural analysis proposed in this article, evaluative vocative expressions form a further illustration of the structural uniformity that is hidden behind superficial diversity.

Acknowledgements I would like to thank Ylva Falk, Jarich Hoekstra, Ora Matushansky, Jairo Nunes, and Tom Roeper for discussion of (certain parts of) this paper. A special thanks to Marcel den Dikken for his very helpful comments and suggestions. Finally, I would also like to express my thanks to the reviewers of the Journal of Comparative Germanic Linguistics for their helpful comments.

Open Access This article is distributed under the terms of the Creative Commons Attribution Noncommercial License which permits any noncommercial use, distribution, and reproduction in any medium, provided the original author(s) and source are credited.

\section{References}

Abney, S. 1987. The English noun phrase in its sentential Aspect. Doctoral dissertation, MIT. Aoun, J., and L. Choueiri. 2000. Epithets. Natural Language and Linguistic Theory 18: 1-39.

Bennis, H., N. Corver., and M. den Dikken. 1998. Predication in nominal phrases. The Journal of Comparative Germanic Linguistics 1: 85-117.

Benveniste, É. 1966. Problèmes de linguistique générale. Paris: Gallimard.

Bolinger, D. 1972. Degree words. The Hague: Mouton.

Chomsky, N. 1993. A minimalist program for linguistics theory. In The view from building 20: Essays in linguistics in honor of Sylvain Bromberger, eds. K. Hale, and S.-J. Keyser, 1-52. Cambridge, MA, USA: MIT Press.

Chomsky, N. 2001. Derivation by phase. In Ken Hale: A Life in Language, ed. M. Kenstowicz, 1-52. Cambridge, MA, USA: MIT Press.

Corver, N. 1990. The syntax of left branch extractions. Doctoral dissertation, Tilburg University. 
Corver, N. 2000. Degree adverbs as displaced predicates. Italian Journal of Linguistics 12: 155-191.

Corver, N. 2003. On three types of movement within the Dutch nominal domain. In From NP to DP, eds. M. Coene, and Y. d'Hulst, 297-328. Amsterdam: John Benjamins.

Corver, N. 2004. Some notes on emphatic forms and displacement in Dutch. In Triggers, eds. A. Breitbarth, and H. van Riemsdijk, 137-172. Berlin: Mouton de Gruyter.

Corver, N. 2007. Dutch 'proper name + $-s$ ': a hidden possessive. In Linguistics in the Netherlands 2007, eds. B.-L. Los, and M. van Koppen. Amsterdam: John Benjamins.

de Bont, A.P. 1958. Dialekt van Kempenland Meer in het bijzonder d'Oerse taol. Deel 1. Klank-en vormleer en enige syntactische bijzonderheden. Assen: Van Gorcum \& Comp. N.V.

De Rooij, J. 1967. Lummel dat je bent. Tijdschrift voor Nederlandse Taal-en Letterkunde 83: 108-121.

Déchaine, R.-M., and M. Wiltschko. 2002. Decomposing pronouns. Linguistic Inquiry 33: 409-442.

Delsing, L.-O. 1988. The Scandinavian noun phrase. Working papers in Scandinavian syntax 42: 57-79.

den Dikken, M. 1995. Copulas. Paper presented at GLOW 18, Tromsø, Unpublished manuscript, Vrije Universiteit Amsterdam/HIL.

den Dikken, M. 1998. Predicate inversion in DP. In Possessors, predicates and movement in the determiner phrase, eds. A. Alexiadou, and C. Wilder, 177-214. Amsterdam/Philadelphia: John Benjamins.

den Dikken, M. 2006. Relators and linkers. The syntax of predication, predicate inversion, and copulas. Cambridge, MA, USA: MIT Press.

Emonds, J. 1976. A transformational approach to English syntax. New York: Academic.

Emonds, J. 1985. A unified theory of syntactic categories. Dordrecht: Foris.

Freeze, R. 1992. Existentials and other locatives. Language 68: 553-595.

Haegeman, L. 2003a. The external possessor construction in West Flemish. In From NP to DP. Volume II: The expression of possession, eds. M. Coene, Y. d'Hulst, and L. Tasmowski, 221-256. Amsterdam: John Benjamins.

Haegeman, L. 2003b. West Flemish possessor doubling and the anaphor agreement effect. In Germania et alia. A linguistic webschrift presented to Hans den Besten, eds. H. van Riemsdijk, and J. Koster, ISBN: 90-9017951-8

Haegeman, L. 2004a. DP periphery and clausal periphery: possessor doubling in West Flemish? Relating Nominal Periphery to Clausal Periphery. In Peripheries, eds. D. Adger, C. de Cat, and G. Tsoulas, 317-339. Dordrecht: Kluwer.

Haegeman, L. 2004b. A DP internal anaphor agreement effect. Linguistic Inquiry 35: 704-712.

Hendrick, R. 1990. Operator binding in NP. In Proceedings of the ninth west coast conference on formal linguistics, ed. A. Halpern. University of Chicago.

Jespersen, O. 1977. The philosophy of grammar. London: George Allen \& Unwin first published in 1924.

Johannessen, J.B. 2006. Just any pronoun anywhere? Pronouns and "new" demonstratives in Norwegian. In A Festschrift for Kjell Johan Sabø: In Partial Fulfilment of the Requirements for the Celebration of his 50th Birthday. 91-106. Oslo: Solstad, Grønn \& Haug.

Julien, M. 2005. Nominal phrases from a Scandinavian perspective. Amsterdam: John Benjamins.

Kayne, R. 1994. The antisymmetry of syntax. Cambridge, MA, USA: MIT Press.

Kayne, R. 2000. Parameters and Universals. Oxford: Oxford University Press.

Kern, J.H. 1927. Jou deugniet!. Nieuwe Taalgids 5: 45-51.

Kester, E.-P. 1996. The nature of adjectival inflection. Doctoral dissertation. Utrecht University.

Koelmans, L. 1978. Inleiding tot het lezen van zeventiende-eeuws Nederlands. Utrecht: Bohn, Scheltema \& Holkema.

Matushansky, O. 2002. Movement of degree/degree of Movement. Doctoral dissertation, MIT.

Moro, A. 1991. The Raising of predicates: Copula, expletives and existence. In MIT Working Papers in Linguistics 15: More Papers on Wh-movement, eds. L. Cheng and H. Demirdache, 193-218. Department of Linguistics and Philosophy, MIT.

Neeleman, A., and F. Weerman. 1999. Flexible syntax: A theory of case and arguments. Dodrecht: Kluwer Academic.

Overdiep, G.S. 1935. Zeventiende-eeuwsche syntaxis. Deel III. Groningen-Batavia: J.B. Wolters' uitgeversmaatschappij N.V.

Pauwels, J.L. 1940. Het element sen in doe sen ezel. In: Handelingen Kon. Com. Top. \& Dialect., XIV, (pp. 55-66). (also appeared in Pauwels, J.L. (1965). Verzamelde opstellen. (pp. 200-207), Assen: Van Gorcum \& COMP. N.V.)

Pauwels, J.L. 1958. Het dialect van Aarschot en omstreken. V. I. Belgisch Interuniversitair Centrum voor Neerlandistiek.

Ponelis, F.A. 1979. Afrikaanse Syntaksis. Pretoria: J.L. van Schaik Akademies. 
Postal, P. 1966. On so-called pronouns in English. In Modern studies in English, eds. D. Reibel, and S. Schane, 201-223. Englewood Cliffs, N.J: Prentice-Hall.

Potts, C., and T. Roeper. 2006. The narrowing acquisition path: From expressive small clauses to declaratives. In The syntax of nonsententials: Multi-disciplinary perspectives, eds. L. Progovac, K. Paesani, E. Casielles, and E. Barton, 183-201. Amsterdam: John Benjamins.

Royen, G. 1948. Buigingsverschijnselen in het Nederlands. deel III/2, Amsterdam.

Szabolcsi, A. 1983. The possessor that ran away from home. The Linguistic Review 3: 89-102.

Szabolcsi, A. 1994. The noun phrase. In The syntax of Hungarian. Syntax and semantics 27, eds. F. Kiefer, and K.É. Kiss, New York: Academic Press.

Trommelen, M., and W. Zonneveld. 1979. Inleiding in de generatieve fonologie. Muiderberg: Coutinho. van Ginneken, J. 1954. Drie Waterlandse dialecten. Dl. I: Grammatica, phonologie, klankleer. bez. door A. Weynen. Alphen a/d Rijn: Samson.

van Kampen, J., and N. Corver. 2006. Diversity of possessor marking in Dutch child language and Dutch dialects. In Proceedings of the 39th linguistics colloquium 2004, ed. M. Vliegen, 385-398. Berlin: Peter Lang.

Weijnen, A.A. 1966. Nederlandse dialectkunde. Assen: Van Gorcum \& Comp N.V.

Weijnen, A.A. 1971. Schets van de geschiedenis van de Nederlandse syntaxis. Assen: Van Gorcum \& Comp, N.V.

Williams, E. 1981. Argument structure and morphology. The Linguistics Review 1: 81-114. 